\title{
Carbon and nitrogen dynamics and greenhouse gas emissions in constructed wetlands treating wastewater: a review
}

\author{
M. M. R. Jahangir ${ }^{1,2}$, K. G. Richards ${ }^{2}$, M. G. Healy ${ }^{3}$, L. Gill ${ }^{1}$, C. Müller ${ }^{4,5}$, P. Johnston ${ }^{1}$, and O. Fenton ${ }^{2}$ \\ ${ }^{1}$ Department of Civil, Structural \& Environmental Engineering, Trinity College Dublin, Dublin 2, Ireland \\ ${ }^{2}$ Department of Environment, Soils \& Land Use, Teagasc Environment Research Centre, Johnstown Castle, \\ Co. Wexford, Ireland \\ ${ }^{3}$ Civil Engineering, National University of Ireland, Galway, Co. Galway, Ireland \\ ${ }^{4}$ School of Biology and Environmental Science, University College Dublin, Belfield, Dublin, Ireland \\ ${ }^{5}$ Department of Plant Ecology (IFZ), Justus-Liebig University Giessen, Giessen, Germany \\ Correspondence to: M. M. R. Jahangir (jahangim@tcd.ie)
}

Received: 19 June 2014 - Published in Hydrol. Earth Syst. Sci. Discuss.: 4 July 2014

Revised: 28 October 2015 - Accepted: 29 November 2015 - Published: 18 January 2016

\begin{abstract}
The removal efficiency of carbon (C) and nitrogen $(\mathrm{N})$ in constructed wetlands (CWs) is very inconsistent and frequently does not reveal whether the removal processes are due to physical attenuation or whether the different species have been transformed to other reactive forms. Previous research on nutrient removal in CWs did not consider the dynamics of pollution swapping (the increase of one pollutant as a result of a measure introduced to reduce a different pollutant) driven by transformational processes within and around the system. This paper aims to address this knowledge gap by reviewing the biogeochemical dynamics and fate of $\mathrm{C}$ and $\mathrm{N}$ in CWs and their potential impact on the environment, and by presenting novel ways in which these knowledge gaps may be eliminated. Nutrient removal in CWs varies with the type of $\mathrm{CW}$, vegetation, climate, season, geographical region, and management practices. Horizontal flow CWs tend to have good nitrate $\left(\mathrm{NO}_{3}^{-}\right)$removal, as they provide good conditions for denitrification, but cannot remove ammonium $\left(\mathrm{NH}_{4}^{+}\right)$due to limited ability to nitrify $\mathrm{NH}_{4}^{+}$. Vertical flow $\mathrm{CWs}$ have good $\mathrm{NH}_{4}^{+}$removal, but their denitrification ability is low. Surface flow CWs decrease nitrous oxide $\left(\mathrm{N}_{2} \mathrm{O}\right)$ emissions but increase methane $\left(\mathrm{CH}_{4}\right)$ emissions; subsurface flow $\mathrm{CWs}$ increase $\mathrm{N}_{2} \mathrm{O}$ and carbon dioxide $\left(\mathrm{CO}_{2}\right)$ emissions, but decrease $\mathrm{CH}_{4}$ emissions. Mixed species of vegetation perform better than monocultures in increasing $\mathrm{C}$ and $\mathrm{N}$ removal and decreasing greenhouse gas (GHG) emissions, but empirical evidence is still scarce. Lower hydraulic loadings with higher hydraulic retention times enhance nutrient removal, but more
\end{abstract}

empirical evidence is required to determine an optimum design. A conceptual model highlighting the current state of knowledge is presented and experimental work that should be undertaken to address knowledge gaps across CWs, vegetation and wastewater types, hydraulic loading rates and regimes, and retention times, is suggested. We recommend that further research on process-based $\mathrm{C}$ and $\mathrm{N}$ removal and on the balancing of end products into reactive and benign forms is critical to the assessment of the environmental performance of CWs.

\section{Introduction}

Increasing anthropogenic loading of reactive nitrogen $(\mathrm{Nr}$; all forms of nitrogen ( $\mathrm{N}$ ) except di-nitrogen gas, $\mathrm{N}_{2}$ ) along the $\mathrm{N}$ cascade in the environment raises many critical concerns for human health, drinking water quality (Gray, 2008), coastal and marine water degradation as well as algal blooms and hypoxia (Conley et al., 2009; Rabalais et al., 2010). Constructed wetlands (CWs) are artificial sinks for $\mathrm{Nr}$ (Galloway et al, 2003; Tanner et al., 2005), and have been successfully used to treat domestic sewage, urban runoff and storm water, industrial and agricultural wastewater, and leachate. While the biogeochemistry of wetlands in general has been discussed in the literature (Whalen, 2005; Reddy and Delaune, 2008), less is known about the delivery pathways of the transformation products of carbon (C) and $\mathrm{N}$ from $\mathrm{CWs}$ treating 
wastewater. Although CWs have a proven potential for organic $\mathrm{C}$ and $\mathrm{N}$ removal, with few exceptions (Dzakpasu et al., 2014), studies have rarely quantified all relevant pathways. This has meant that reported removal efficiencies have been variable (Seitzinger et al., 2002). If the fate of $\mathrm{C}$ and $\mathrm{N}$ is accurately quantified, appropriate design and management strategies may be adopted.

Constructed wetlands are complex bioreactors that facilitate a number of physical, chemical, and biological processes, but are frequently evaluated as a black box in terms of process understanding (Langergraber, 2008). Many investigations target single contaminant remediation and disregard the reality of mixed contaminants entering and leaving CWs. They do not consider the dynamics of pollution swapping (the increase in one pollutant as a result of a measure introduced to reduce a different pollutant) driven by transformational processes within and around the system. This means that potential negative impacts that CWs may have on the environment, such as greenhouse gas (GHG) emissions (IPCC, 2013; Clair et al., 2002; Mander et al., 2008; Mitsch and Gosselink, 2000) or enhancement of pollution swapping (Reay, 2004), are not accounted for in analyses. There are many pathways by which the removed $\mathrm{N}$ can contribute to water and air pollution: accumulation and adsorption in soils, leaching of nitrate $\left(\mathrm{NO}_{3}^{-}\right)$and ammonium $\left(\mathrm{NH}_{4}^{+}\right)$to groundwater, emissions of nitrous oxide $\left(\mathrm{N}_{2} \mathrm{O}\right)$ and ammonia $\left(\mathrm{NH}_{3}^{+}\right)$ to the atmosphere, and/or conversion to $\mathrm{N}_{2}$ gas. Constructed wetlands significantly contribute to atmospheric $\mathrm{N}_{2} \mathrm{O}$ emissions either directly to the atmosphere from the surface of the wetland (IPCC, 2013; Søvik et al., 2006; Ström et al., 2007; Elberling et al., 2011) or indirectly via dissolved $\mathrm{N}_{2} \mathrm{O}$ in the effluent or groundwater upon discharge to surface waters. The IPCC (2013) has recognized the significance of indirect $\mathrm{N}_{2} \mathrm{O}$ emissions from $\mathrm{CW}$ effluent that is discharged to aquatic environments, and estimate emission factors (EF) ranging from 0.0005 to 0.25 . Production and reduction processes of $\mathrm{N}_{2} \mathrm{O}$ in the environment are not yet fully understood.

Constructed wetlands receive organic $\mathrm{C}$ from the influent wastewater and from fixation by the photosynthetic hydrophytes, which are incorporated into soil as organic C. Soil organic $\mathrm{C}$ undergoes the biogeochemical processes that regulate $\mathrm{C}$ accretion in soil and microbial respiration, producing carbon dioxide $\left(\mathrm{CO}_{2}\right)$. Anaerobic mineralization of organic $\mathrm{C}$ by methanogenic archaea can produce methane $\left(\mathrm{CH}_{4}\right)$ (Laanbroek, 2010; Ström et al., 2007; Søvik et al., 2006; Pangala et al., 2010). Constructed wetlands can also contribute to the dissolved organic carbon (DOC) load transfer to groundand surface waters, which may produce and exchange substantial amounts of $\mathrm{CO}_{2}$ and $\mathrm{CH}_{4}$ with the atmosphere (Clair et al., 2002; Elberling et al., 2011). Therefore, CWs can diminish the environmental benefits of wastewater treatment. The dynamics of dissolved $\mathrm{N}_{2} \mathrm{O}, \mathrm{CO}_{2}$, and $\mathrm{CH}_{4}$ in $\mathrm{CWs}$ is a key knowledge gap in global GHG budgets.
Surface emissions of GHG from CWs have been commonly measured by the closed chamber method (Johansson et al., 2003, 2004; Mander et al., 2005, 2008), but have rarely been measured by ebullition and diffusion methods (Søvik et al., 2006). The measured rates have shown high spatial, temporal, and diurnal variations due to the change in biogeochemistry of $\mathrm{C}$ and $\mathrm{N}$ and plant-microbe-soil interaction over time and space. Surface emissions cannot explain the kinetics of production and consumption rates of GHG, which we need to know in order to adopt better management practices to mitigate emissions. In addition, subsurface export of dissolved nutrients and GHG, an important pathway of nutrient loss (Riya et al., 2010), is frequently ignored. Mass balance analysis of the different components of the $\mathrm{N}$ cycle and kinetics of their transformation processes occurring within the treatment cells using the isotope-tracing ${ }^{15} \mathrm{~N}$ technique can provide mechanistic information for $\mathrm{N}$ transformation products (Lee et al., 2009; O'Luanaigh et al., 2010) and may be used to start to answer such questions. Similarly, ${ }^{14} \mathrm{C}$ application and measurement of $\mathrm{C}$ species (e.g. $\mathrm{CO}_{2}, \mathrm{CH}_{4}$, and DOC) may elucidate the $\mathrm{C}$ mineralization and $\mathrm{CO}_{2}$ and $\mathrm{CH}_{4}$ production and consumption. Used in combination, these methods may provide a comparative analysis of the rates of $\mathrm{C}$ and $\mathrm{N}$ transformation processes and the role of these processes in delivering $\mathrm{NO}_{3}^{-}, \mathrm{NH}_{4}^{+}$, and DOC to ground/surface waters and $\mathrm{N}_{2} \mathrm{O}, \mathrm{CO}_{2}$, and $\mathrm{CH}_{4}$ to the atmosphere.

Past reviews on CWs, though very limited, summarize the performance of different types of CWs on $\mathrm{C}$ and $\mathrm{N}$ removal (Vymazal, 2007) and surface emissions of GHG (Mander et al., 2014), but have not discussed the mechanisms of nutrient removal and the fate of the nutrients delivered and removed to and from CWs. Therefore, the objectives of this review are to (i) understand the biogeochemical dynamics of $\mathrm{C}$ and $\mathrm{N}$ in CWs, (ii) better understand the fate of various $\mathrm{C}$ and $\mathrm{N}$ species in a holistic manner, in addition to the conventional influent/effluent balance for nutrient removal, (iii) identify the research gaps that need to be addressed to optimize nutrient removal and mitigate GHG emissions, and (iv) discuss emerging measurement techniques that may give insights into the production and reduction of GHG.

\section{Removal efficiency, hydraulic loading, and retention time}

In CWs, the efficiency of $\mathrm{C}$ and $\mathrm{N}$ removal is generally limited and highly variable over $\mathrm{CW}$ types, plant types, seasons, climatic regions, and management practices. On average, it appears that 50 and $56 \%$ of the influent total nitrogen (TN) and total organic carbon (TOC), respectively, can be removed, but the removal rates are very inconsistent. Mean ( \pm standard error) TN removals, obtained from the literature cited in this paper, ranged from $31.3 \pm 6.3 \%$ in surface flow (SF) CWs to $40.4 \pm 4.4 \%$ in subsurface flow (SSF) CWs, 
Table 1. $\mathrm{TN}$ input $\left(\mathrm{mg} \mathrm{N} \mathrm{L}^{-1}\right)$, $\mathrm{TN}$ output (TN, $\mathrm{mg} \mathrm{N} \mathrm{L}^{-1}$ ), and $\mathrm{TN}$ removal (\%) in various $\mathrm{CWs}$ treating wastewater; average standard error $( \pm \mathrm{SE})$ is presented for TN removal; NA - data not available.

\begin{tabular}{|c|c|c|c|c|c|c|c|c|c|c|c|}
\hline \multirow[t]{2}{*}{$\mathrm{CW}$ type } & \multirow[t]{2}{*}{ Treatment } & \multicolumn{3}{|c|}{$\mathrm{N}$ input $\left(\mathrm{mg} \mathrm{N} \mathrm{L}^{-1}\right)$} & \multicolumn{3}{|c|}{$\mathrm{N}$ output $\left(\mathrm{mg} \mathrm{NL}^{-1}\right)$} & \multicolumn{3}{|c|}{$\mathrm{N}$ removal $(\%)$} & \multirow[t]{2}{*}{ References } \\
\hline & & $\mathrm{TN}$ & $\mathrm{NH}_{4}^{+}$ & $\mathrm{NO}_{3}^{-}$ & $\mathrm{TN}$ & $\mathrm{NH}_{4}^{+}$ & $\mathrm{NO}_{3}^{-}$ & $\mathrm{TN}$ & $\mathrm{NH}_{4}^{+}$ & $\mathrm{NO}_{3}^{-}$ & \\
\hline SF_Finland & Municipal & $1.4 \pm 150$ & $0.03 \pm 5.8$ & $0.3 \pm 95$ & $1.1 \pm 48$ & $0.01 \pm 3.0$ & $0.02 \pm 6.7$ & 21.4 & 66.7 & 93.3 & Søvik et al. (2006) \\
\hline SF_Finland & Agril. runoff & $66.1 \pm 1.9$ & $63.5 \pm 1.3$ & $0.7 \pm 0.13$ & $64.7 \pm 1.7$ & $61.2 \pm 1.7$ & $0.3 \pm 0.09$ & 2.1 & 3.6 & 57.1 & Søvik et al. (2006) \\
\hline SF_Norway & Municipal & $43.4 \pm 3.6$ & $41.5 \pm 3.0$ & $0.0 \pm 0.0$ & $36.7 \pm 2.7$ & $32.6 \pm 1.9$ & $0.9 \pm 0.4$ & 15.4 & 21.4 & -800 & Søvik et al. (2006) \\
\hline $\mathrm{SF}$ & Municipal & NA & 4.5 & 15.5 & NA & NA & NA & 61 & NA & NA & Song et al. (2011) \\
\hline SF & Domestic & NA & 40 & 5 & NA & NA & NA & $97-98$ & NA & NA & Dzakpasu et al. (2011) \\
\hline SF & Various & NA & 39 & 4.4 & NA & NA & NA & $39-48$ & NA & NA & Vymazal (2007) \\
\hline SF & Municipal & NA & 36 & & NA & NA & NA & 39 & NA & NA & Vymazal (2010) \\
\hline SF & Municipal & NA & 196 & $<2$ & NA & NA & NA & 35 & NA & NA & Shamir et al. (2001) \\
\hline SF & various & NA & 80 & $<1$ & NA & NA & NA & $>90$ & NA & NA & Harrington et al. (2007) \\
\hline SF & Municipal & NA & 0.95 & 1.54 & NA & NA & NA & 45 & NA & NA & Toet et al. (2005) \\
\hline $\mathrm{SF}$ & Dairy washout & 227 & NA & NA & NA & NA & NA & 40 & NA & NA & Van der Zaag et al. (2010) \\
\hline \multicolumn{8}{|l|}{ All SF } & \multicolumn{4}{|l|}{$31.3 \pm 6.3$} \\
\hline HSSF_Estonia & Municipal & $96.5 \pm 3.0$ & $83.9 \pm 2.7$ & $0.2 \pm 0.02$ & $46.2 \pm 1.5$ & $36.2 \pm 1.4$ & $5.9 \pm 0.65$ & 52.1 & 56.9 & -2850 & Søvik et al. (2006) \\
\hline HSSF_Norway & Municipal & $53.4 \pm 4.3$ & $38.4 \pm 7.7$ & $14.1 \pm 7.5$ & $45.0 \pm 4.1$ & $43.1 \pm 4.7$ & $1.0 \pm 0.8$ & 15.7 & -12.2 & 92.9 & Søvik et al. (2006) \\
\hline HSSF & Dairy washout & $306 \pm 101^{*}$ & NA & NA & $177 \pm 58^{*}$ & NA & NA & 42.2 & NA & NA & Van der Zaag et al. (2010) \\
\hline HSSF & Domestic & NA & 74.9 & 3.9 & NA & NA & NA & 29 & NA & NA & O'Luanaigh et al. (2010) \\
\hline HSSF & Domestic & 87 & & & & & & $46-48$ & & & Mander et al. (2008) \\
\hline HSSF & Dairy washout & 227 & & & & & & 28 & & & Van der Zaag et al. (2010) \\
\hline HSSF & Milk parlour & 112 & 22 & NA & 24 & 11 & NA & 78 & 50 & $\mathrm{NA}$ & Kato et al. (2006) \\
\hline HSSF & Agriculture & 67 & 40 & 0.85 & 27 & 11 & 1.1 & 47 & 39 & -29 & Vymazal and Kröpfelova (2010) \\
\hline HSSF & Industry & 124 & 65 & 8.5 & 103 & 31 & 7.4 & 20 & 20 & 8 & Vymazal and Kröpfelova (2010) \\
\hline HSSF & Landfill & 157 & 149 & 1.5 & 147 & 98 & 1.3 & 30 & 33 & 31 & Vymazal and Kröpfelova (2010) \\
\hline HSSF & Municipal & 43 & 24 & 2 & 24 & 14 & 1.2 & 40 & 30 & 33 & Vymazal and Kröpfelova (2010) \\
\hline \multicolumn{8}{|l|}{ All HSSF } & \multicolumn{4}{|l|}{$40.4 \pm 4.4$} \\
\hline VSSF_Estonia & Municipal & $50.9 \pm 9.2$ & $35.7 \pm 6.2$ & $1.1 \pm 0.32$ & $43.1 \pm 7.6$ & $31.7 \pm 5.5$ & $1.7 \pm 0.84$ & 15.3 & 11.2 & -54.5 & Søvik et al. (2006) \\
\hline VSSF_Norway & Municipal & $52.6 \pm 5.2$ & $49.6 \pm 4.0$ & $0.0 \pm 0.0$ & $47.8 \pm 6.9$ & $21.4 \pm 6.9$ & $25.5 \pm 1.3$ & 9.1 & 56.9 & -25400 & Søvik et al. (2006) \\
\hline VSSF & Municipal & $41.0 \pm 0.5$ & NA & NA & $20.7 \pm 0.8$ & NA & NA & $49.3 \pm 1.8$ & NA & NA & Yan et al. (2012) \\
\hline VSSF & Municipal & $46 \pm 13$ & NA & NA & NA & NA & NA & $74 \pm 3$ & NA & NA & Zhao et al. (2014) \\
\hline All VSSF & & & & & & & & $37.0 \pm 10.9$ & & & \\
\hline
\end{tabular}

$\mathrm{SF}$ - surface flow; HSSF - horizontal subsurface flow; VSSF - vertical subsurface flow; ${ }^{*} \mathrm{mg} \mathrm{N} \mathrm{m}^{-2} \mathrm{~h}^{-1}$.

Table 2. Total organic C (TOC) removal (\%) in various CWs treating wastewater; average standard error ( \pm SE) is presented for TOC removal; NA - data not available.

\begin{tabular}{llllll}
\hline CWs type & Treatment & C input (TOC; $\left.\mathrm{mg} \mathrm{CL}^{-1}\right)$ & C output (TOC; $\left.\mathrm{mg} \mathrm{CL}^{-1}\right)$ & TOC Removal (\%) & References \\
\hline SF_Finland & Municipal & $13.0 \pm 0.3$ & $14.0 \pm 0.5$ & -7.7 & Søvik et al. (2006) \\
SF_Finland & Agril runoff & $25.0 \pm 3.4$ & $20.0 \pm 3.4$ & 20.0 & Søvik et al. (2006) \\
SF_Norway & Municipal & $26.7 \pm 2.9$ & $17.1 \pm 1.8$ & 36.0 & Søvik et al. (2006) \\
SF & Dairy wash out & $186^{\mathrm{a}}$ & $136^{\mathrm{a}}$ & 27 & Van der Zaag et al. (2010) \\
All SF & & & $18.8 \pm 9.4$ & \\
\hline HSSF & Domestic & $150^{\mathrm{b}}$ & $\mathrm{NA}$ & $\mathrm{NA}$ & Garcia et al. (2007) \\
HSSF & Dairy wash out & $186^{\mathrm{a}}$ & $107.9^{\mathrm{a}}$ & 42 & Van der Zaag et al. (2010) \\
HSSF_Estonia & Municipal & $62.8 \pm 16.6^{\mathrm{a}}$ & $41.0 \pm 11.3^{\mathrm{a}}$ & 34.7 & Søvik et al. (2006) \\
HSSF_Norway & Municipal & $40.5 \pm 11.3$ & $15.0 \pm 2.4$ & 63.0 & Søvik et al. (2006) \\
All HSSF & & & $46.6 \pm 7.3$ & \\
\hline VSSF_Estonia & Municipal & $132.2 \pm 32.2^{\mathrm{a}}$ & $62.8 \pm 16.6^{\mathrm{a}}$ & 52.5 & Søvik et al. (2006) \\
VSSF_Norway & Municipal & $40.5 \pm 11.3$ & $15.0 \pm 2.4$ & 63.0 & Søvik et al. (2006) \\
VSSF & Municipal & $106 \pm 35$ & $74 \pm 21$ & $83 \pm 4.6$ & Yan et al. (2012) \\
VSSF & Municipal & $249 \pm 49$ & NA & $56.2 \pm 9.5$ & Zhao et al. (2014) \\
All VSSF & & & &
\end{tabular}

$\mathrm{SF}$ - surface flow; HSSF - horizontal subsurface flow; VSSF - vertical subsurface flow; ${ }^{\mathrm{a}} \mathrm{BOD} ;{ }^{\mathrm{b}} \mathrm{mg} \mathrm{m}^{-2} \mathrm{~h}^{-1}$.

whereas TOC removal ranged from $18.8 \pm 9.4 \%$ in SF CWs to $56.2 \pm 9.5 \%$ in vertical subsurface flow CWs (Tables 1 and 2). In European systems, for example, typical removals of ammoniacal $\mathrm{N}$ in long-term operation are around $35 \%$, but can be enhanced if some pre-treatment procedures are followed (Verhoeven and Meuleman, 1999; Luederitz et al.,
2001). Generally, TN removal is higher in SF CWs than SSF CWs (Table 1), but studies differ. For example, Van der Zaag et al. (2010) showed higher $N$ removal in SF CWs than SSF CWs, but Søvik et al. (2006) and Gui et al. (2007) showed the opposite. In SSF CWs, limited removal can be caused by a reduced environment that enhances $\mathrm{NH}_{4}^{+}$accumulation and 
limits $\mathrm{NH}_{4}^{+}$oxidation. In $\mathrm{SF}$ CWs, denitrification rates can be limited due to lack of $\mathrm{NO}_{3}^{-}$. In vertical subsurface flow (VSSF) CWs, aeration can increase $\mathrm{NH}_{4}^{+}$oxidation to $\mathrm{NO}_{3}^{-}$, which can be denitrified or converted to $\mathrm{NH}_{4}^{+}$by dissimilatory $\mathrm{NO}_{3}^{-}$reduction to $\mathrm{NH}_{4}^{+}$(DNRA).

Plant species are important components of CWs, and affect $\mathrm{C}$ and $\mathrm{N}$ removals. Optimal species selection for best removal is difficult because some species are efficient in removing one pollutant but not the other (Bachand and Horne, 2000; Bojcevska and Tonderski, 2007; da Motta Marques et al., 2001). In some studies there are no inter-species differences at all (Calheiros et al., 2007). Mixed species perform better than monocultures to remove $\mathrm{C}$ and $\mathrm{N}$ pollutants because they increase microbial biomass and diversity. Payne et al. (2014a) discussed the role of plants in nutrient removal. Plants regulate $\mathrm{CW}$ hydrology (evaporation and transpiration) and temperature (insulating CWs from seasonal temperature change, trapping falling and drifting snow, and heat loss of wind). Some species can create a large surface area for microbial attachment and enhance microbial diversity, but experimental evidence is still scarce.

Soil physico-chemical properties, such as permeability (Dzakpasu et al., 2014) and cation exchange capacity (Drizo et al., 1999) are important factors controlling the purification capacity in CWs. Microbial activities and growth depend on substrate $\mathrm{C}$ quality and $\mathrm{C}: \mathrm{N}$ ratios, which affect nutrient removal. Growth of heterotrophic microorganisms is a function of the wastewater C: N (Makino et al., 2003). High C: N ratios can enhance denitrification by providing electron donors for denitrifiers, but the opposite can increase nitrification. High C: N ratios can also encourage DNRA over denitrification. Yan et al. (2012) measured a high TN removal but low TOC removals at a $\mathrm{C}: \mathrm{N}$ ratio $2.5: 1$, which indicates that removal of one parameter might lead to a problem with a different one. The uncertainty in the conditions for achievement of optimum removal suggests that the rates of $\mathrm{C}$ and $\mathrm{N}$ transformations and the fate of the removed nutrients within $\mathrm{CWs}$ should be investigated. However, to our knowledge, no study has provided a holistic evaluation of $\mathrm{C}$ and $\mathrm{N}$ attenuation and transformation.

The removal of pollutants in CWs depends on hydraulic loading rates (HLR) and hydraulic retention time (HRT) (Toet et al., 2005). The HLR and HRT are considered to be significant design parameters determining the nutrient removal efficiencies (Weerakoon et al., 2013). Longer HRTs of wastewater in CWs increase the removal of $\mathrm{C}$ and $\mathrm{N}$ (Wang et al., 2014) by increasing sedimentation and duration of contact between nutrients and the CWs. The effects of HLR and HRT can vary with the nature of the use of CWs, e.g. whether they are used for treating single or mixed pollutants. To reduce $\mathrm{Nr}$ delivery to the receiving waters or to the atmosphere, CWs need to be optimally designed with respect to HLR and HRT.
Fluctuating hydraulic loading influences all biotic and abiotic processes in CWs (Mander et al., 2011). For example, if the groundwater table is lowered through changes in hydraulic loading, soil aeration can increase or decrease. Ammonification and nitrification rates increase with increased soil aeration and this enhances $\mathrm{C}$ utilization by bacteria and, therefore, can stimulate the removal of $\mathrm{C}$ and $\mathrm{N}$. Investigation into the effects of fluctuating hydraulic loadings (hydraulic pulsing) on $\mathrm{C}$ and $\mathrm{N}$ removals and their transformation products will provide information about the fate of the added nutrients in terms of their environmental benefits and/or pollution swapping potential. For example, if the dominant product is $\mathrm{N}_{2}$, the system will be relatively benign in terms of its impact on the environment, but if it is $\mathrm{NH}_{4}^{+}$, it can be fixed in the soils or transported to ground- and surface waters connected to CWs if the cation exchange sites become saturated. Several authors have used a wide range of HLRs and HRTs to measure nutrient removal efficiency, but experimental evidence linking HLR and HRT to removal efficiency is scarce (Toet et al., 2005). Luo et al. (2005) reported that low HLR results in incomplete denitrification, whereas Zhang et al. (2006) argued that low HLR increases $\mathrm{NH}_{4}^{+}$and chemical oxygen demand oxidation. The way in which the performance of a CW is assessed can lead to different conclusions regarding the removal of Nr. For future studies, evaluation of CWs in a holistic manner, which includes pollution swapping at different HLRs and HRTs, is important, particularly within the context of the changing hydrologic cycle in a changing climate. In addition, local legislative targets should be considered and weighting factors (e.g. the relative importance of, say, GHG over water quality targets) should be developed to evaluate the overall performance of CWs. In addition to the estimation of nutrient removal rates, investigation of the effect of HLR and HRT on the different forms of nutrients in the final effluent and their fate in the natural environment may help elucidate the pollution swapping potential of CWs.

\section{Accumulation of $\mathrm{C}$ and $\mathrm{N}$ in $\mathrm{CWs}$ soils}

The soil in CWs is a major sink for $\mathrm{C}$ and $\mathrm{N}$ (Mustafa and Scholz, 2011). However, although data on the influent and effluent $\mathrm{N}$ concentrations are available, data on $\mathrm{N}$ accumulation (dissolved organic nitrogen (DON), TN, $\mathrm{NH}_{4}^{+}$, or $\mathrm{NO}_{3}^{-}-$ $\mathrm{N})$ within the soil profile of various CWs are scarce. The wide range of $\mathrm{N}$ accumulation reported in the literature (e.g. 30-40\%, Shamir et al., 2001; 39\%, Harrington et al., 2007; $9 \%$, Mander et al., 2008; $2.5 \%$, Obarska-Pempkowiak and Gajewska, 2003) may be due to the variations in CW types and management strategies. The accumulated species of $\mathrm{N}$ are reactive unless they have been transformed to $\mathrm{N}_{2}$ by biogeochemical processes. However, there is a dearth of information on the extent of $\mathrm{Nr}$ accumulation in soils and discharge to surface waters and air (Shamir et al., 2001). Accumulated organic $\mathrm{N}$ could be mineralized to $\mathrm{NH}_{4}^{+}$and $\mathrm{NO}_{3}^{-}$, 
depending on the physico-chemical properties of soil. The $\mathrm{Nr}$ could be assimilated by plants and microbes, which are recycled in a soil-plant-soil continuum. Nitrogen spiralling occurs from $\mathrm{NH}_{4}^{+}$to organic $\mathrm{N}$ and back to $\mathrm{NH}_{4}^{+}$within the CW (O'Luanaigh et al., 2010). Typically, $\mathrm{N}$ accumulation has been found to decrease with soil depth (Shamir et al., 2001). In terms of the conventional input-output balance, these are considered as removed $\mathrm{N}$, but may, in fact, remain in such a biogeochemically active system. In addition to N, organic C accumulation occurs in CW soils (Nguyen, 2000).

Soils of CWs represent organic $\mathrm{C}$ and $\mathrm{Nr}$-rich systems, where the products of continuously occurring biogeochemical processes, such as accumulation in soil and transportation to fresh waters and to the atmosphere, need to be quantified. Such an approach will show the shortcomings of conventional removal efficiency estimation methods and will also demonstrate how the apparently removed $\mathrm{C}$ and $\mathrm{N}$ species can become a source of contamination. Estimation of the rates of nutrient accumulation in soils in various types of CWs under different management systems is important. The stability of the accumulated $\mathrm{C}$ and $\mathrm{N}$ under changing climatic scenarios also needs to be addressed to consider the longterm sustainability of CWs.

\section{$4 \mathrm{C}$ and $\mathrm{N}$ dynamics and greenhouse gas emissions}

Increased nutrient input to $\mathrm{CWs}$ increases the productivity of wetland ecosystems and the production of GHG. As CWs are designed to remove pollutants in an anaerobic/suboxic environment, they change the $\mathrm{C}$ and $\mathrm{N}$ biogeochemistry and contribute significantly to $\mathrm{CH}_{4}$ and $\mathrm{N}_{2} \mathrm{O}$ emissions (Johansson, 2002, Johansson et al., 2003; Mander et al., 2005, 2008; Stadmark and Leonardson, 2005; Liikanen et al., 2006). Søvic et al. (2006) measured $\mathrm{N}_{2} \mathrm{O}, \mathrm{CH}_{4}$, and $\mathrm{CO}_{2}$ emissions in various CWs in different European countries, and suggested that the potential atmospheric impacts of CWs should be examined as their development is increasing globally. Management of CWs must consider the negative climatic aspects of increased emissions of GHG in addition to their primary functions (Ström et al., 2007). Therefore, estimation of the contribution of $\mathrm{CWs}$ to global warming is required. In this regard, measurement of spatial and temporal variations (seasonal and diurnal) of GHG emissions is necessary to accurately estimate $\mathrm{CW}$-derived GHG emissions. A holistic assessment of ecologically engineered systems has been outlined by Healy et al. $(2011,2014)$ and developed further by Fenton et al. (2014). Such assessments can be applied in evaluating nutrient dynamics in CWs. Moreover, plant mediated GHG emissions could be an important component of total emissions, but again research in this area is very limited. Effective modelling or up-scaling of GHG emissions from watershed to regional/national scales is important for the improvement of global GHG budgets. Such up-scaling needs an accurate estimation of $\mathrm{C}$ and $\mathrm{N}$ inputs and outputs, i.e. a balance coupled with net GHG emissions, while considering all possible processes and pathways involved. A study of the dynamics of $\mathrm{C}$ and $\mathrm{N}$ in $\mathrm{CWs}$ is crucial, as the forms of removed $\mathrm{C}$ and $\mathrm{N}$ are particularly pertinent to their potential for pollution swapping, global warming, and water pollution.

Processes involved in $\mathrm{N}$ removal and $\mathrm{N}$ transformations in wetlands include sedimentation of particulates (Koskiaho, 2003), nitrification, denitrification, DNRA (Poach et al., 2003; Burgin et al., 2013), microbial assimilation and plant uptake-release (Findlay et al., 2003), and anammox (anaerobic ammonium oxidation) and deamox (DEnitrifying AMmonium OXidation). Constructed wetlands are complex systems that facilitate aerobic and anaerobic microsites (Wynn and Liehr, 2001). Nitrification, denitrification, and nitrifier denitrification are the processes responsible for the production of $\mathrm{N}_{2} \mathrm{O}$. Depending on the environmental conditions or management practices prevailing, a certain process will dominate; e.g., denitrification is the dominant process in SF CWs (Beaulieu et al., 2011), but nitrifier denitrification is dominant in VSSF CWs (Wunderlin et al., 2013). Generally, CWs are anaerobic but aquatic macrophytes can transport oxygen from the atmosphere to the rooting zone, where it can sustain nitrification. The existence of microsites that support high activity and promote denitrification has been shown in soils (Parkin, 1987). Such conditions are also likely to occur in CWs, which have patchy distributions of organic material (e.g. particulate organic carbon), due to rhizodepositions (Minett et al., 2013; Hamersley and Howes, 2002). Minett et al. (2013) found that simultaneous oxygenation of the rhizosphere, through radial oxygen loss, and enhanced oxygen consumption by the soil occurs in the area immediately surrounding the roots. Nitrate produced in the rooting zone can be taken up by plants or denitrified and/or converted back to $\mathrm{NH}_{4}^{+}$by DNRA.

Competition for $\mathrm{NO}_{3}^{-}$may occur between denitrification and biotic assimilation. This is likely governed by the prevailing aerobic/anaerobic conditions and therefore dependent on the type of wetland. For instance, in storm water biofiltration systems, prolonged periods of inundation and dry periods may support bio-assimilation over denitrificaton (Payne et al., 2014a, b).

The conditions that favour the occurrence of either denitrification or DNRA are still in debate (Rütting et al., 2011). DNRA is thought to be favoured by a $\mathrm{C}: \mathrm{NO}_{3}^{-}$ratio of $>12$ (Rütting et al., 2011) and occurs at low levels of oxidationreduction potential (Thayalakumaran et al., 2008). The differences between denitrification and DNRA may be due to the availability of organic matter, because DNRA is favoured at a high $\mathrm{C}: \mathrm{NO}_{3}^{-}$ratio and denitrification is favoured when carbon supplies are limiting (Korom, 2002; Kelso et al., 1997). The fermentative bacteria that carry out DNRA are obligate anaerobes, and so cannot occupy all the niches that denitrifiers can (Buss et al., 2005). Takaya (2002) stated that a more reducing state favours DNRA over denitrification. 
Pett-Ridge et al. (2006) showed that DNRA is less sensitive to dissolved oxygen (DO) than denitrification. Fazzolari et al. (1998) showed that the partitioning between DNRA and denitrification depends on the $\mathrm{C}: \mathrm{NO}_{3}^{-}$ratio and $\mathrm{C}$ rather than DO.. Significant DNRA may occur only at a $\mathrm{C}: \mathrm{NO}_{3}^{-}$ratio above 12 (Yin et al., 1998). Different numbers of electrons are required in the reduction of each $\mathrm{NO}_{3}^{-}$molecule: five for denitrification and eight for DNRA. Therefore, more organic matter can be oxidized for each molecule of $\mathrm{NO}_{3}^{-}$by DNRA than by denitrification. In addition, $\mathrm{NO}_{3}^{-}$reduction is generally performed by fermentative bacteria that are not dependent on the presence of $\mathrm{NO}_{3}^{-}$for growth under anaerobic conditions. Therefore, DNRA bacteria may be favoured in $\mathrm{NO}_{3}^{-}$-limited conditions (Laanbroek, 1990). Recent studies have suggested that DNRA may be an important process compared to denitrification in wetland sediments (Burgin and Hamilton, 2008). Van Oostrom and Russell (1994) found a $5 \%$ contribution of DNRA to $\mathrm{NO}_{3}^{-}$removal in CWs. Little is known about the eventual fate of the $\mathrm{NO}_{3}^{-}$that is converted to $\mathrm{NH}_{4}^{+}$via DNRA pathways. In recent years, $\mathrm{N}$-cycling studies have increasingly investigated DNRA in various ecosystems to explore its importance in N cycling (Rütting et al., 2011), but controls on DNRA are relatively unknown (Burgin et al., 2013), DNRA being probably the least studied process of $\mathrm{N}$ transformation in wetlands (Vymazal, 2007). However, DNRA can be a significant pathway of $\mathrm{NO}_{3}^{-}$reduction that impacts on the $\mathrm{CW}$ ecosystem services and so should therefore be evaluated.

Denitrification has been estimated to be a significant $\mathrm{N}$ removal process, but actual quantification data are scarce. Few studies have estimated $\mathrm{N}$ losses by denitrification, e.g. $19 \%$ (Mander et al., 2008) and $86 \%$ (Obarska-Pempkowiak and Gajewska, 2003) of the total $\mathrm{N}$ input based on the mass balance study. To our knowledge, no data are available on denitrification measurements in soil/subsoils of surface flow CWs. While many of these pathways transfer $\mathrm{Nr}$ (mainly $\mathrm{NH}_{4}^{+}$and $\mathrm{N}_{2} \mathrm{O}$ ) to the environment, other pathways can convert $\mathrm{Nr}$ to $\mathrm{N}_{2}$ (e.g. denitrification, anammox, and deamox). Anammox can remove $\mathrm{NO}_{2}^{-}$and $\mathrm{NH}_{4}^{+}$as $\mathrm{N}_{2}$ when the existing environment is hypoxic. Deamox can remove $\mathrm{NO}_{3}^{-}$and $\mathrm{NH}_{4}^{+}$as $\mathrm{N}_{2}$, where $\mathrm{NO}_{3}^{-}$is converted to $\mathrm{NO}_{2}^{-}$by autotrophic denitrification with sulfide (Kalyuzhnyi et al., 2006). In CWs, anammox and deamox are not well understood, so it is crucial to identify which of the processes are occurring in a specific type of $\mathrm{CW}$ and the rate at which they occur. Once a process that provides $\mathrm{N}_{2}$ as the end product is determined, then the management of the CW can be directed towards enhancement of that process. Hence, quantifying the rates of these processes for various types of $\mathrm{CW}$ is required for improved $\mathrm{N}$ management towards lowering $\mathrm{Nr}$ in the environment.

The various components of the $\mathrm{C}$ cycle include: fixation of $\mathrm{C}$ by photosysnthesis, respiration, fermentation, methanogenesis , and $\mathrm{CH}_{4}$ oxidation with reduction of sulfur, iron, and
$\mathrm{NO}_{3}^{-}$. Anaerobic methane oxidation coupled with denitrification, a recently proposed pathway of the C cycle (á Norði and Thamdrup, 2014; Haroon et al., 2013; Islas-Lima et al., 2004), can reduce $\mathrm{CH}_{4}$ emissions in CWs. The $\mathrm{C}$ removal processes are sedimentation, microbial assimilation, gaseous emissions, dissolved $\mathrm{C}$ losses through water to ground- and surface water bodies, and chemical fixation (bonding with chemical ions). Net primary productivity of wetland hydrophytes varies across CW type, season, climatic region, and local environmental conditions. For example, results can vary remarkably for CWs containing the same plant species in different geographical regions (Brix et al., 2001). The rate of carbon mineralization in $\mathrm{CW}$ sediments depends on the redox chemistry of soil, the bio-availability of organic $\mathrm{C}$ and temperature. In particular, areas of sediment subjected to prolonged low redox conditions (e.g, $-150 \mathrm{mV}$ ) are conducive to methanogens and rates of $\mathrm{CH}_{4}$ emissions exceeding $132 \mathrm{mg} \mathrm{m}^{-2} \mathrm{~d}^{-1}$ (Brix et al., 2001), but this is highly variable depending on $\mathrm{C}: \mathrm{N}$ ratio of the influent water and wetland seasonality. In summer, oxygen diffusion to the topsoil can reduce methanogenesis and stimulate $\mathrm{CH}_{4}$ oxidation (Grünfeld and Brix, 1999). However, an increase in temperature can decrease DO in deeper subsoil layers, which can enhance $\mathrm{CH}_{4}$ production. As in all biochemical reactions, temperature increases $\mathrm{C}$ and $\mathrm{N}$ turnover in $\mathrm{CWs}$, causing high variations in GHG emissions in different types of CWs in different regions (temperate/tropical/arctic). This warrants the acquisition of more measurement data across $\mathrm{CW}$ types and regions for the better extrapolation of GHG emissions. The $\mathrm{C}: \mathrm{N}$ ratios of wastewater affect microbial growth and development that, in turn, affect their response to $\mathrm{C}$ and $\mathrm{N}$ cycles and GHG emissions. Previous research on the effects of $\mathrm{C}: \mathrm{N}$ ratios on nutrient removal and GHG emissions is limited. A few examples include Yan et al. (2012) and Zhao et al. (2014), who measured lower $\mathrm{CO}_{2}$ and $\mathrm{CH}_{4}$ emissions at $\mathrm{C}: \mathrm{N}$ ratios of between $2.5: 1$ and $5: 1$, but this lower range of $\mathrm{C}: \mathrm{N}$ ratios decreased TOC removal. Hence, investigation of the influence of $\mathrm{C}: \mathrm{N}$ ratio on nutrient removal efficiencies and GHG emissions across $\mathrm{CW}$ and management types is crucial.

Emissions of GHG in CWs can vary across CW typologies, e.g. surface flow or subsurface flow (Tables 3 and 4). Generally, $\mathrm{CH}_{4}$ emissions are higher in SF CWs than in SSF CWs (Table 3), but may vary with season, which requires investigation. Nitrous oxide and $\mathrm{CO}_{2}$ emissions are higher in VSSF CWs than horizontal subsurface flow (HSSF) and SF CWs. The $\mathrm{N}_{2} \mathrm{O} E F\left(\mathrm{~N}_{2} \mathrm{O} / \mathrm{TN}\right.$ input $\left.\times 100\right)$ ranged from $0.61 \pm 0.21 \%$ in SF CWs to $1.01 \pm 0.48 \%$ in VSSF CWs. The EF for $\mathrm{CH}_{4}$ emissions ranged from $1.27 \pm 0.31 \%$ in VSSF CWs to $16.8 \pm 3.8 \%$ in SF CWs. The GHG from CWs can vary between vegetated and non-vegetated systems (Table 5).

Aquatic plants play an important role in GHG production and transport to the atmosphere by releasing GHG through their interconnected internal gas lacunas (Laanbroek, 2010). Emergent plants can transport atmospheric oxygen to the 
Table 3. Nitrous oxide $\left(\mathrm{N}_{2} \mathrm{O}\right)$ emissions $\left(\mathrm{mg} \mathrm{N} \mathrm{m}^{-2} \mathrm{~d}^{-1}\right) ; \mathrm{N}_{2}$ emissions $\left(\mathrm{mg} \mathrm{N} \mathrm{m}^{-2} \mathrm{~d}^{-1}\right)$ and $\mathrm{N}_{2} \mathrm{O}$ emission factor $\left(\mathrm{N}_{2} \mathrm{O} / \mathrm{TN}\right.$ input $\left.\times 100\right)$ in various type of CWs; mean standard error $\left( \pm \mathrm{SE}\right.$ ) was presented for $\mathrm{N}_{2} \mathrm{O}$ emission factor; $\mathrm{NA}$ - data not available.

\begin{tabular}{|c|c|c|c|c|c|c|}
\hline \multirow[t]{2}{*}{ CW type } & \multirow[t]{2}{*}{ Treatment } & \multicolumn{2}{|c|}{ Denitrification } & \multirow[t]{2}{*}{$\mathrm{N}_{2} \mathrm{O}-\mathrm{N} / \mathrm{TN}(\%)$} & \multirow[t]{2}{*}{$\mathrm{N}_{2}-\mathrm{N} / \mathrm{TN}(\%)$} & \multirow[t]{2}{*}{ References } \\
\hline & & $\begin{array}{l}\mathrm{N}_{2} \mathrm{O} \text { emissions } \\
\left(\mathrm{mg} \mathrm{N} \mathrm{m}^{-2} \mathrm{~d}^{-1}\right)\end{array}$ & $\begin{array}{l}\mathrm{N}_{2} \text { emissions } \\
\left(\mathrm{mg} \mathrm{N} \mathrm{m}^{-2} \mathrm{~d}^{-1}\right)\end{array}$ & & & \\
\hline $\mathrm{HSF}$ & Agril. tile drainage & $0.01-0.12$ & NA & $0.19-1.4$ & NA & Xue et al. (1999) \\
\hline HSF & Treated municipal & $2.0 \pm 3.3$ & NA & $0.02-0.27$ & NA & Johansson et al. (2003) \\
\hline HSF & Agril. drainage & $-0.2-1.9$ & NA & $-0.14-0.52$ & NA & Wild et al. (2002) \\
\hline HSF & Dairy wash out & $16.8 \pm 7.0$ & NA & $0.33 \pm 0.12$ & NA & Van der Zaag et al. (2010) \\
\hline HSF_Finland & Municipal & $0.01 \pm 0.01$ & NA & $1.6 \pm 1.3$ & NA & Søvik et al. (2006) \\
\hline HSF_Finland & Agril. runoff & $0.40 \pm 0.25$ & NA & $0.37 \pm 0.18$ & NA & Søvik et al. (2006) \\
\hline HSF_Norway & Municipal & $4.0 \pm 1.6$ & NA & $1.5 \pm 4.4$ & NA & Søvik et al. (2006) \\
\hline All SF & & $2.78 \pm 1.72$ & & $0.61 \pm 0.21$ & & \\
\hline HSSF & Domestic & $0.2-17.0$ & NA & $0.06-3.8$ & NA & Mander et al. (2005) \\
\hline HSSF_Estonia & Municipal & $7.1 \pm 1.2$ & NA & $0.05 \pm 0.31$ & NA & Søvik et al. (2006) \\
\hline HSSF_Norway & Municipal & $6.9 \pm 4.3$ & NA & $0.24 \pm 0.53$ & NA & Søvik et al. (2006) \\
\hline HSSF & Domestic & $1.3-1.4$ & $160-170$ & $0.37-0.60$ & $15.2-22.7$ & Mander et al. (2008) \\
\hline HSSF & Domestic & $0.003-0.001$ & $0.01-5.42$ & NA & NA & Teiter and Mander (2005) \\
\hline HSSF & Domestic & 0.13 & NA & 0.008 & NA & Fey et al. (1999) \\
\hline HSSF & Dairy wash out & $9.5 \pm 1.5$ & NA & $0.18 \pm 0.12$ & NA & Van der Zaag et al. (2010) \\
\hline HSSF & Domestic & 0.17 & NA & 0.23 & NA & Liu et al. (2009) \\
\hline VSSF & Domestic & 0.17 & NA & 0.01 & & Mander et al. (2011) \\
\hline All HSSF & & $4.23 \pm 1.87$ & & $0.62 \pm 0.38$ & & \\
\hline VSSF & Domestic & $0.001-0.002$ & $0.01-5.0$ & NA & NA & Teiter and Mander (2005) \\
\hline VSSF & Domestic & 4.6 & 150 & $0.45-0.50$ & NA & Mander et al. (2008) \\
\hline VSSF & Domestic & 11.0 & NA & 0.29 & NA & Mander et al. (2005) \\
\hline VSSF & Domestic & 1.44 & NA & 0.03 & & Mander et al. (2011) \\
\hline VSSF & Domestic & 0.005 & NA & 0.09 & NA & Gui et al. (2007) \\
\hline VSSF & Domestic & 0.003 & NA & 0.04 & NA & Liu et al. (2009) \\
\hline VSSF_Estonia & Municipal & $15 \pm 3.9$ & NA & $04.3 \pm 0.95$ & NA & Søvik et al. (2006) \\
\hline VSSF_Norway & Municipal & $960 \pm 40$ & NA & $1.4 \pm 0.72$ & NA & Søvik et al. (2006) \\
\hline All VSSF & & $123.8 \pm 106$ & & $1.01 \pm 0.48$ & & \\
\hline
\end{tabular}

SF - surface flow; HSSF - horizontal subsurface flow; VSSF - vertical subsurface flow.

rooting zone and contribute to increased $\mathrm{N}_{2} \mathrm{O}$ and $\mathrm{CO}_{2}$ production and $\mathrm{CH}_{4}$ consumption (Brix, 1997). Vascular plants can exchange GHG between the rooting zone and atmosphere (Yavitt and Knapp, 1998). Vegetation and its composition affect the nutrient dynamics and the production, consumption, and transport of GHG and hence their exchange between wetlands and atmosphere (Ström et al., 2003, 2005; Søvic et al., 2006; Johansson et al., 2003). They can also affect the biogeochemistry of CWs due to the differences in their growth and development, longevity, root systems, root density, root depth, and microbial ecology in the rhizosphere. As some plant litter decomposes, organic matter with lignocellulose and humic compounds may be released that are more or less labile or stable in nature than others. Release of low molecular weight organic matter that is labile in nature is more likely to produce GHGs than stable forms. For example, Z. latifolia showed higher nutrient removal and $\mathrm{CH}_{4}$ fluxes than P. australis (Inamori et al., 2007). The Z. lotifolia root system is shallow and the activity of methanotrophs is primarily confined to the top soil. The root systems of $P$. australis are deeper, which is more favourable for the oxidization of $\mathrm{CH}_{4}$.
A fluctuating water table in CWs has significant impacts on GHG dynamics. Pulsing hydrologic regimes decreases $\mathrm{CH}_{4}$ but increases $\mathrm{N}_{2} \mathrm{O}$ emissions (Mander et al., 2011). In aerobic and anaerobic conditions caused by pulsing hydrology, incomplete nitrification and denitrification increase $\mathrm{N}_{2} \mathrm{O}$ emissions (Healy et al. 2007). However, the effects of pulsing hydrologic regimes on GHG emissions are contradictory. For example, intermittent hydrologic regimes decrease both $\mathrm{N}_{2} \mathrm{O}$ (Sha et al., 2011) and $\mathrm{CH}_{4}$ emissions (Song et al., 2010). Highly contrasting results on gas emissions with fluctuating water levels have been reported and the controlling mechanisms are unclear (Elberling et al., 2011).

Therefore, the assessment of GHG emissions in various types of CWs (surface flow, subsurface flow, vertical and horizontal), vegetation cover (vegetated, non-vegetated) and species type, and management system employed (HLR, HRT, soil used, and water table), is necessary in light of the national and global GHG budgets. In addition, such measurements will help scientists, environmental managers, and policy makers adopt environmentally friendly construction and management of CWs. The enhanced reduction of $\mathrm{N}_{2} \mathrm{O}$ to $\mathrm{N}_{2}$ needs further elucidation. 
Table 4. Carbon dioxide $\left(\mathrm{CO}_{2} ; \mathrm{mg} \mathrm{C} \mathrm{m}^{-2} \mathrm{~d}^{-1}\right), \mathrm{CH}_{4}\left(\mathrm{mg} \mathrm{C} \mathrm{m}^{-2} \mathrm{~d}^{-1}\right)$, and $\mathrm{CH}_{4}$ emission factor $\left(\mathrm{CH}_{4}-\mathrm{C} / \mathrm{TOC}\right.$ input $\left.\times 100\right)$ in various types of CWs; mean standard error $( \pm \mathrm{SE})$ was presented for $\mathrm{CH}_{4}$ emission factor; $\mathrm{NA}$ - data not available.

\begin{tabular}{|c|c|c|c|c|c|}
\hline CWs type & Treatment & $\begin{array}{l}\mathrm{CO}_{2} \text { emissions } \\
\left(\mathrm{mg} \mathrm{C} \mathrm{m}^{-2} \mathrm{~d}^{-1}\right)\end{array}$ & $\begin{array}{l}\mathrm{CH}_{4} \text { emissions } \\
\left(\mathrm{mg} \mathrm{Cm}^{-2} \mathrm{~d}^{-1}\right)\end{array}$ & $\mathrm{CH}_{4} / \mathrm{TC}(\%)$ & References \\
\hline SF & Municipal & NA & 5.4 & NA & Tai et al. (2002) \\
\hline SF & Domestic & 0.19 & NA & 26 & Gui et al. (2007) \\
\hline SF & Domestic & 1.13 & NA & 16 & Liu et al. (2009) \\
\hline SF & Agril. drainage & NA & 0.88 & 31 & Wild et al. (2002) \\
\hline SF & Dairy wash out & $4250 \pm 550$ & $223 \pm 35$ & 9.45 & Van der Zaag et al. (2010) \\
\hline SF_Finland & Municipal & $1200 \pm 420$ & $29 \pm 6.4$ & $19 \pm 4.3$ & Søvik et al. (2006) \\
\hline SF_Finland & Agril runoff & $3200 \pm 560$ & $350 \pm 180$ & $11 \pm 5.5$ & Søvik et al. (2006) \\
\hline SF_Norway & Municipal & $1400 \pm 250$ & $72 \pm 28$ & $4.8 \pm 2.2$ & Søvik et al. (2006) \\
\hline All SF & & $1675 \pm 703$ & $113 \pm 58$ & $16.8 \pm 3.8$ & \\
\hline HSSF & Domestic & NA & $1.7-528$ & NA & Mander et al. (2005) \\
\hline HSSF & Domestic & $2.54-5.83$ & $0.03-0.40$ & NA & Teiter and Mander (2005) \\
\hline HSSF & Domestic & 5.33 & 0.001 & 0.03 & Garcia et al. (2007) \\
\hline HSSF & Domestic & NA & 0.03 & 4.3 & Gui et al. (2007) \\
\hline HSSF & Domestic & NA & 0.29 & 4.0 & Liu et al. (2009) \\
\hline HSSF & Dairy wash out & $3475 \pm 375$ & $118 \pm 9.0$ & 4.4 & Van der Zaag et al. (2010) \\
\hline HSSF & Domestic & $0.6-1.7$ & $1.4-4.1$ & $0.12-0.23$ & Søvik et al. (2006) \\
\hline HSSF & Domestic & 600 & 0.48 & 0.02 & Mander et al. (2011) \\
\hline HSSF_Estonia & Municipal & $3800 \pm 210$ & $340 \pm 240$ & NA & Søvik et al. (2006) \\
\hline HSSF_Norway & Municipal & $790 \pm 170$ & $130 \pm 43$ & $9.5 \pm 3.3$ & Søvik et al. (2006) \\
\hline All HSSF & & $1010 \pm 672$ & $112 \pm 74$ & $3.23 \pm 1.4$ & \\
\hline VSSF & Domestic & $5.83-12.13$ & $0.60-5.70$ & & Teiter and Mander (2005) \\
\hline VSSF & Domestic & NA & 16.4 & NA & Mander et al. (2005) \\
\hline VSSF & Domestic & NA & 0.013 & 1.68 & Gui et al. (2007) \\
\hline VSSF & Domestic & NA & 0.13 & 1.73 & Liu et al. (2009) \\
\hline VSSF & Municipal & $2662 \pm 175$ & $33.5 \pm 3.2$ & NA & Mander et al. (2008) \\
\hline VSSF & Domestic & 1080 & 3.36 & 0.05 & Mander et al. (2011) \\
\hline VSSF_Estonia & Municipal & $8400 \pm 2100$ & $110 \pm 35$ & NA & Søvik et al. (2006) \\
\hline VSSF_Norway & Municipal & $22000 \pm 5000$ & $140 \pm 160$ & $0.39 \pm 0.27$ & Søvik et al. (2006) \\
\hline All VSSF & & $6616 \pm 3779$ & $42.9 \pm 23.7$ & $1.27 \pm 0.31$ & \\
\hline
\end{tabular}

SF - surface flow; HSSF - horizontal subsurface flow; VSSF - vertical subsurface flow.

\section{Surface emissions vs. subsurface export of C and N}

Dissolved GHG produced in soils and subsoils can be emitted to the atmosphere by transpiration of vascular plants (from within the rooting zone), ebullition, and diffusion from soils. Elberling et al. (2011) reported that in wetlands, the transport of gases through subsoil occurs both via diffusive transport in the pores and through the vascular plants. Surface emissions of GHG from CWs have recently been recognized and have been commonly measured by chamber methods (Mander et al., 2008, 2011). As is the case with other dissolved pollutants (Dzakpasu et al., 2014), the GHG produced in CWs can also be transported to the groundwater with the percolating water and emitted to the atmosphere upon discharge to surface waters (Riya et al., 2010). It can also flow towards surface waters by advective transport and/or by dispersion of groundwater. Dissolved nutrients can be preferentially leached down into deeper soil layers and groundwater via different pathways (e.g. root channels). The $\mathrm{Nr}$ delivered to groundwater can be transformed in situ to other reactive or benign forms. Hence, quantification of such $\mathrm{Nr}$ loadings to groundwater and their in situ consumption (e.g. $\mathrm{N}_{2} \mathrm{O}$ to $\mathrm{N}_{2}$ or $\mathrm{CH}_{4}$ to $\mathrm{CO}_{2}$ ) is necessary to understand their environmental consequences. In addition, $\mathrm{DON}, \mathrm{NO}_{3}^{-}, \mathrm{NH}_{4}^{+}$, and DOC delivered to surface waters can undergo biochemical reactions and produce $\mathrm{N}_{2} \mathrm{O}, \mathrm{CO}_{2}$, and $\mathrm{CH}_{4}$ in streams and estuaries. Ström et al. (2007) measured a considerable quantity of $\mathrm{CH}_{4}$ in porewater and found a correlation between the surface emissions and porewater $\mathrm{CH}_{4}$ concentrations in vegetated wetlands. Measuring only the surface emissions of GHG can omit substantial quantities of GHG released from CWs. For example, Riya et al. (2010) measured emissions of $\mathrm{CH}_{4}$ and $\mathrm{N}_{2} \mathrm{O}$, accounting for 2.9 and $87 \%$ of the total emissions. Measuring porewater GHG and linking these to the surface emissions and subsurface export to groundwater below CWs will help to estimate a better GHG balance from both a national and global context. Elberling et al. (2011) 
Table 5. Nitrous oxide $\left(\mathrm{N}_{2} \mathrm{O} ; \mathrm{mg} \mathrm{N} \mathrm{m}^{-2} \mathrm{~d}^{-1}\right), \mathrm{CO}_{2}$, and $\mathrm{CH}_{4}$ emissions $\left(\mathrm{mg} \mathrm{C} \mathrm{m}^{-2} \mathrm{~d}^{-1}\right)$ in various type of $\mathrm{CWs}$ under different plant types; NA - data not available.

\begin{tabular}{|c|c|c|c|c|c|c|}
\hline CW type & Wastewater type & Plant type & $\begin{array}{l}\mathrm{N}_{2} \mathrm{O} \\
\left(\mathrm{mg} \mathrm{N} \mathrm{m}^{-2} \mathrm{~d}^{-1}\right)\end{array}$ & $\begin{array}{l}\mathrm{CH}_{4} \\
\left(\mathrm{mgC} \mathrm{m}^{-2} \mathrm{~d}^{-1}\right)\end{array}$ & $\begin{array}{l}\mathrm{CO}_{2} \\
\left(\mathrm{mg} \mathrm{m}^{-2} \mathrm{~d}^{-1}\right)\end{array}$ & Reference \\
\hline \multirow[t]{6}{*}{ HSF } & Secondary treated & No plant & $3.79 \pm 2.64$ & $163 \pm 209$ & & $\begin{array}{l}\text { Johansson et al. (2003); } \\
\text { Johansson et al. (2004) }\end{array}$ \\
\hline & municipal & Typha lotifolia & $2.64 \pm 4.09$ & $109 \pm 185$ & NA & \\
\hline & & Phalaris arundinacea & $3.79 \pm 3.44$ & $212 \pm 151$ & NA & \\
\hline & & Glyceria maxima & $0.76 \pm 1.01$ & $112 \pm 178$ & NA & \\
\hline & & Lemna minor & $1.45 \pm 1.18$ & $450 \pm 182$ & NA & \\
\hline & & Spirogyra sp. & $0.98 \pm 1.25$ & $107 \pm 135$ & NA & \\
\hline \multirow[t]{4}{*}{ HSF } & Sewage treatment & No plant & $-0.26 \pm 2.53$ & $-4.76 \pm 61.8$ & $4.32 \pm 0.73$ & Ström et al. (2007) \\
\hline & water & Typha atifolia & $4.94 \pm 2.00$ & $225 \pm 47.7$ & $25.3 \pm 4.08$ & \\
\hline & & Phragmites australis & $7.80 \pm 2.53$ & $333 \pm 76.6$ & $25.1 \pm 4.74$ & \\
\hline & & Juncus effusus & $3.87 \pm 1.86$ & $489 \pm 46.3$ & $26.1 \pm 3.00$ & \\
\hline \multirow[t]{4}{*}{ HSSF } & Domestic & No plant & $0.04 \pm 0.02$ & $87 \pm 6.3$ & $80 \pm 6.3$ & Maltais-Landry et al. (2009) \\
\hline & & Phragmites & $0.06 \pm 0.03$ & $50 \pm 7.5$ & $200 \pm 35$ & \\
\hline & & Typha & $0.03 \pm 0.01$ & $28 \pm 3.0$ & $235 \pm 32$ & \\
\hline & & Phalaris & $0.01 \pm 0.01$ & $45 \pm 6.0$ & $195 \pm 31$ & \\
\hline VSSF & Municipal & Phragmites australis & $15 \pm 3.9$ & $110 \pm 35$ & $8400 \pm 2100$ & Søvik et al. (2006) \\
\hline VSSF & Municipal & Phragmites australis & 264 & 384 & & Mander et al. (2005) \\
\hline
\end{tabular}

$\mathrm{SF}$ - surface flow; HSSF - horizontal subsurface flow; VSSF - vertical subsurface flow.

linked subsurface gas concentrations in wetlands to the surface fluxes using a diffusion model. This demonstrates the need for future studies on subsurface GHG production, consumption and net GHG emissions in CWs within a climate change context.

It is important to characterize soils and subsoils' physical (e.g. texture, bulk density) and hydraulic (development of a soil water characteristic curve) properties and to assess their potential to percolate dissolved nutrients and gases in the solute phase to the underlying groundwater. To our knowledge, the indirect pathway of GHG emissions from CWs has never been reported, despite the fact that this would appear to have a high biogeochemical potential to produce and exchange GHG. The balance between $\mathrm{N}$ and $\mathrm{C}$ input and output flows between CWs and aquatic and atmospheric environments, together with the direct and indirect emissions of $\mathrm{C}$ and $\mathrm{N}$ species, could be an important input to global $\mathrm{C}$ and $\mathrm{N}$ budgets.

\section{Hydrogeochemistry below CWs}

Constructed wetlands can be designed with or without a clay liner or a compacted soil bed at the base, which can lead to large differences in permeability of the underlying layers. The variation in permeability of a CW soil bed will affect solute, nutrient, and GHG flows, and their interactions with the underlying groundwater (Dzakpasu et al., 2012, 2014). Groundwater hydrogeochemistry below CWs can therefore provide a unique insight into such interactions. An example of such interactions would be between nutrient-rich water discharging from $\mathrm{CW}$ cells mixing with laterally moving regional groundwater. It should be noted that groundwater can also discharge into CWs depending on the hydraulic gradi- ents. This means that fully screened, multi-level piezometers or boreholes should be installed at such sites to elucidate groundwater flow direction, hydraulic gradients, and conductivities. Such monitoring networks allow water samples to be collected and the sources of nutrients in groundwater bodies below CWs to be identified. The local site hydrology (precipitation, groundwater table fluctuations, and evapotranspiration) has a large impact on the pollutant removal. Hydrogeochemical studies at an accurate spatial and temporal resolution should explain the effects of precipitation on nutrient removal by dilution as well in situ nutrient turnover. Effective $\mathrm{CW}$ management requires an understanding of the effects of wetland hydrology on the physical and biochemical attenuation of nutrients in order to assess their impacts on the surface emissions and subsurface export of nutrients and GHG. Data on the species of $\mathrm{N}$ in groundwater below the CWs are required to provide an in-depth understanding of wetland ecosystem services, particularly if CWs have the potential to leak pollutants down into the groundwater (Dzakpasu et al., 2014). Higher $\mathrm{NH}_{4}^{+}$concentrations in groundwater below the $\mathrm{CW}$ than the effluent are often reported (Harrington et al., 2007; Dzakpasu et al., 2012). Therefore, questions arise with respect to $\mathrm{NH}_{4}^{+}$concentrations in groundwater below the CWs if they have been transported from CWs. Linking geochemistry of groundwater below CWs to site hydrology, water table fluctuations, and soil/subsoil physico-chemical properties is required to elucidate the major environmental drivers of $\mathrm{C}$ and $\mathrm{N}$ removal, and/or pollution swapping. The quality of groundwater underlying CWs with regards to the $\mathrm{Nr}$ species is largely unknown. 


\section{Methodological developments}

To improve the ecosystem services and to minimize the pollution swapping of CWs, quantification of $\mathrm{N}$ cycling is crucial. Measurement of GHG using the closed chamber method is widely used, but has large uncertainty in estimating the diurnal variability due to internal changes in temperature and physical access to the chambers over a $24 \mathrm{~h}$ time period. Gas ebullition and diffusion measurements are quite challenging in CWs covered by vegetation, because of the difficulties in estimation of gas transfer velocity. Application of the eddycovariance method is not appropriate for most CWs, as it requires a large surface area ( $>$ several ha) to avoid contribution of surrounding area and complication of GHG foot printing. A combination of chamber, ebullition, and diffusion methods in a single system could minimize the uncertainly in GHG estimation. The methane ebullition measurement was found to be similar to surface emissions by the chamber method, but $\mathrm{N}_{2} \mathrm{O}$ and $\mathrm{CO}_{2}$ ebullition measurements were lower than the surface emissions (Søvik et al., 2006).

The use of in situ microcosm studies and soil core incubation methods may give a better estimation of $\mathrm{N}_{2} \mathrm{O}, \mathrm{CO}_{2}$, and $\mathrm{CH}_{4}$ production and consumption than existing methods. With the recent advancement of isotope pairing and dilution techniques, single or simultaneously occurring $\mathrm{C}$ and $\mathrm{N}$ transformation processes can be quantified in laboratory or in situ conditions (Huygens et al., 2013; Müller et al., 2014). The isotope technique relies on the introduction of a known amount of ${ }^{14} \mathrm{C}$ and or ${ }^{15} \mathrm{~N}$ into the $\mathrm{CW}$ and then quantification of $\mathrm{C}$ and $\mathrm{N}$ concentrations and isotopic compositions through different $\mathrm{C}$ and $\mathrm{N}$ pools after incubation for a specific period. Laboratory methods involve collection of intact soil/sediment cores, with subsequent incubation in the laboratory. In situ field techniques involve the release of a ${ }^{14} \mathrm{C} /{ }^{15} \mathrm{~N}$ solution in the $\mathrm{CW}$ soils. Incubation of intact soil cores with differentially labelled ${ }^{15} \mathrm{NH}_{4}^{14} \mathrm{NO}_{3}$ and ${ }^{14} \mathrm{NH}_{4}^{15} \mathrm{NO}_{3}$ can be used to quantify the rates of different $\mathrm{N}$ transformation processes (Rütting and Müller, 2008). The quantification of simultaneously occurring $\mathrm{N}$ transformation rates rely on the analysis with appropriate ${ }^{15} \mathrm{~N}$-tracing models. In recent years, ${ }^{15} \mathrm{~N}$-tracing techniques have evolved, and are now able to identify process-specific $\mathrm{NO}_{2}^{-}$pools (Rütting and Müller 2008), pathway-specific $\mathrm{N}_{2} \mathrm{O}$ production, and emission, as well as $\mathrm{N}_{2} \mathrm{O}: \mathrm{N}_{2}$ ratios (Müller et al., 2014). Traditional techniques for investigation of gross $\mathrm{N}$ dynamics in sediments (Blackburn, 1979) may be combined with the latest ${ }^{15} \mathrm{~N}$-tracing techniques, where all $\mathrm{N}$ transformation rates are included (Huygens et al., 2013). Thus, current models should consider processes such as anammox and/or deamox, and then be tested in CWs under various operational conditions. Denitrification in porewater samples can be measured by analysing samples for dissolved $\mathrm{N}_{2}$ in a membrane inlet mass spectrometer (MIMS; Kana et al., 1994) and $\mathrm{N}_{2} \mathrm{O}$ in a gas chromatograph (GC; Jahangir et al., 2012). The studies of natural abundance of ${ }^{15} \mathrm{~N}$ and ${ }^{18} \mathrm{O}\left(\delta^{15} \mathrm{~N}\right.$ and $\delta^{18} \mathrm{O}$ ) in $\mathrm{NO}_{3}^{-}$is an insightful tool for the investigation of the sources, fate, and transformational processes of $\mathrm{N}$ in a system (e.g. in shallow groundwater; Baily et al., 2011). The in situ $\mathrm{NO}_{3}^{-}$push-pull method has been used to determine denitrification in shallow groundwater $(<3 \mathrm{~m})$ in riparian wetlands (Addy et al., 2002; Kellogg et al., 2005) and in deep groundwater in arable/grassland (Jahangir et al., 2013).

Isotope-based techniques can also be extended to other elements; e.g., a ${ }^{33}$ P-tracing model has been developed recently to study phosphorus (P) cycle in soil (Müller and Bünemann, 2014). These techniques can be applied in the study of $\mathrm{C}, \mathrm{N}$, and $\mathrm{P}$ biogeochemistry in aquatic environments. In addition, measurements of DOC and gases $\left(\mathrm{CO}_{2}\right.$ and $\mathrm{CH}_{4}$ ) will provide insights into the $\mathrm{C}$ consumption and transformation associated with the $\mathrm{N}$ transformations. Carbon and $\mathrm{N}$ dynamics are influenced by the interacting effects of soil conditions with microbial community structure and functioning. Microbial functioning involves transcription of genes, translation of messenger RNA, and activity of enzymes (Firestone et al., 2012). As such, activities of microbial communities under various environmental conditions and how these contribute to $\mathrm{C}$ and $\mathrm{N}$ dynamics is a very important area of future research (Müller and Clough, 2014). Molecular approaches can be important tools for identifying and quantifying the genes that code for enzyme-mediating $\mathrm{C}$ and $\mathrm{N}$ cycles (Peterson et al., 2012). These tools help assess the relationships among genes, environmental controllers, and the rates of $\mathrm{C}$ and $\mathrm{N}$ processes. The scientific tools and multi-disciplinary techniques are now available to better understand $\mathrm{C}$ and $\mathrm{N}$ transformation rates, processes, and factors controlling the unwanted emission of $\mathrm{N}$ and $\mathrm{C}$ products to the environment.

\section{Conclusions and recommendations}

The transformational processes on a mixture of contaminants within and below CWs can cause pollution swapping. A holistic assessment of $\mathrm{C}$ and $\mathrm{N}$ dynamics in CWs is needed to fully understand their removal, transport, and impact on water quality and emissions to atmosphere. Mixed contaminants entering CWs and those formed within and underneath CWs during transformational processes must be considered in future studies. The overall balance of these constituents will determine whether a $\mathrm{CW}$ is a pollution source or a sink. This will necessitate a higher degree of multi-level spatial and temporal monitoring and the use of multi-disciplinary in and ex situ techniques to fully characterize all pathways of $\mathrm{C}$ and $\mathrm{N}$ loss. At this time we cannot suggest any design optima in terms of nutrient removal and GHG mitigation because empirical information is not yet abundant. To do this, transformation kinetics of $\mathrm{C}$ and $\mathrm{N}$ and net GHG emissions through all possible pathways are required to provide a holistic assessment. However, a combination of various types of $\mathrm{CW}$ and plant types could provide higher removals and lower 


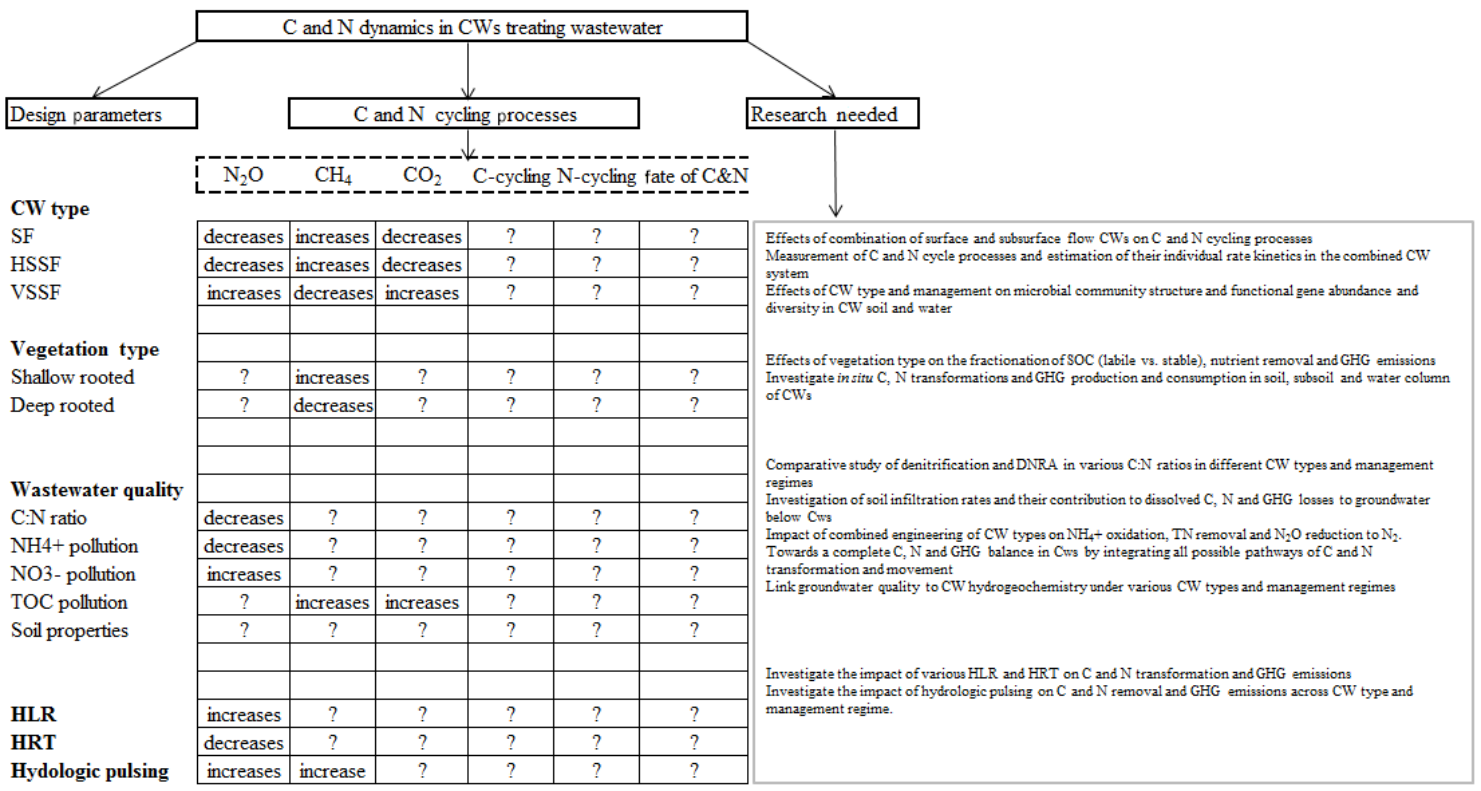

Figure 1. Conceptual model showing the current state of knowledge of $\mathrm{C}$ and $\mathrm{N}$ dynamics in constructed wetlands treating wastewater and the specific experimental work that needs to be undertaken in the future; SF - surface flow; HSSF - horizontal subsurface flow; VSSF vertical subsurface flow; HLR - hydraulic loading rate; HTR - hydraulic retention time; ? - not known or very little known.

GHG emissions. A conceptual model highlighting the current state of knowledge in this area and the research gaps is presented in Fig. 1.

Subsurface export of nutrients and GHG to groundwater should be accounted for in CW management. Reducing the saturated hydraulic conductivity below the wetland bed will help reduce nutrients leaching to groundwater. The reactive versus the benign forms of the $\mathrm{N}$ transformation products should be evaluated. Data on when, where, and the rates at which denitrification, deamox, and anammox occur in CWs are needed, as well as identification of the key factors that control such processes. The provenance of $\mathrm{NH}_{4}^{+}$in groundwater below $\mathrm{CW}$ cells and its impact on down-gradient receptors needs further elucidation. Constructed wetlands have the potential to produce $\mathrm{N}_{2} \mathrm{O}$, DON, DOC, dissolved inorganic $\mathrm{C}$ (DIC), $\mathrm{CO}_{2}$, and $\mathrm{CH}_{4}$, which may be exported to fresh waters via groundwater and degassed upon discharge to surface waters. Moreover, the DOC and DIC transferred to the fresh water sediments (rivers and lakes) can produce GHG that, in turn, emit to the atmosphere. The amount of C and $\mathrm{N}$ exported from terrestrial ecosystems via the subsurface pathway to fresh waters has been the missing piece of our understanding of global $\mathrm{C}$ and $\mathrm{N}$ budgets. It is clear that data on the various $\mathrm{C}$ and $\mathrm{N}$ species, along with the GHG emissions, are crucial to make a robust input-output balance of $\mathrm{C}$ and $\mathrm{N}$ in CWs. Spatial and temporal variations of GHG emissions in CWs under different management systems are also critical to get much more rigorous estimates of emission factors. These data will reduce the existing uncertainties in global $\mathrm{C}$ and $\mathrm{N}$ budgets.
Managing wetting and drying spells (pulsing hydrology) in CWs can enhance $\mathrm{NH}_{4}^{+}$removal. Similarly, oxidation of organic $\mathrm{C}$ will increase $\mathrm{CO}_{2}$ production and, in anaerobic conditions, may be reduced to $\mathrm{CH}_{4}$. This requires more research into the $\mathrm{C}$ and $\mathrm{N}$ cycle processes over the wetting and drying spells, which is now possible with the advancement in ${ }^{14} \mathrm{C} /{ }^{15} \mathrm{~N}$-tracing and modelling techniques. The selection of appropriate plant species is important to optimize nutrient removal, sequester C, and decrease GHG emissions, but more research is needed across species and geographical locations. Further research is also needed to investigate the impacts of hydraulic retention time on nutrient dynamics. Rates of nutrient accumulation or fixation in soils and their in situ transformation in CWs need to be quantified to evaluate their contribution to $\mathrm{C}$ sequestration and GHG emissions.

Author contributions. The first author, M. M. R. Jahangir has reviewed articles in the relevant area, analysed results, identified knowledge gaps, and prepared the draft paper. All co-authors were directly involved in preparation of the paper and edited the paper for its improvement.

Acknowledgements. The research was funded by Irish Research Council and Department of Agriculture, Food and Marine in Association with The University of Dublin, Trinity College.

Edited by: M. Hipsey 


\section{References}

á Norði, K. and Thamdrup, B.: Nitrate-dependent anaerobic methane oxidation in a freshwater sediment, GeochiM. Cosmochim. Acta, 132, 141-150, 2014.

Addy, K., Kellogg, D. Q., Gold, A. J., Groffman, P. M., Ferendo, G., and Sawyer, C.: In situ push-pull method to determine groundwater denitrification in riparian zones, J. Environ. Qual., 31, 10171024, 2002.

Bachand, P. A. M. and Horne, A. J.: Denitrification in constructed free-water surface wetlands: II. Effects of vegetation and temperature, Ecol. Eng., 14, 17-32, 2000.

Baily, A., Rock, L., Watson, C. J., and Fenton, O.: Spatial and temporal variations in groundwater nitrate at an intensive dairy farm in south-east Ireland: Insights from stable isotope data, Agril. Ecosysts. Environ., 308-318, 2011.

Beaulieu, J. J., Tank, J. L., Hamilton, S. K., Wollheim, W. M., Hall, R. O., and Mulholland, P. J.: Nitrous oxide emission from denitrification in stream and river networks, P. Natl. Acad. Sci., 108, 214-219, 2011.

Blackburn, T. H.: Methods for measuring rates of $\mathrm{NH}_{4}^{+}$turnover in anoxic marine sediments, using a ${ }^{15} \mathrm{~N}^{-\mathrm{NH}_{4}^{+}}$dilution technique, Appl. Environ. Microbiol., 37, 760-765, 1979.

Bojcevska, H. and Tonderski, K.: Impact of loads, season, and plant species on the performance of a tropical constructed wetland polishing effluent from sugar factory stabilization ponds, Ecol. Eng., 29, 66-76, 2007.

Brix, H.: Do macrophytes play a role in constructed treatment wetlands, Water Sci. Technol., 35, 11-17, 1997.

Brix, H., Sorrell, B. K., and Lorenzen, B.: Are Phragmitesdominated wetlands a net source or net sink of greenhouse gases?, Aquat. Bot., 69, 313-324, 2001.

Burgin, A. J., Hamilton, S. K., Gardner, W. S., and McCarthy, M. $\mathrm{J} .:$ Nitrate reduction, denitrification, and dissimilatory nitrate reduction to ammonium in wetland sediments, in: Methods in Biogeochemistry of Wetlands, edited by: DeLaune, R. D., Reddy, K. R., Richardson, C. J., and Megonigal, J. P., SSSA Book Series, no. 10, Madison, USA, 307-325, 2013.

Calheiros, C. S. C., Rangel, A. O. S. S., and Castro, P. M. L.: Constructed wetland systems vegetated with different plants applied to the treatment of tannery wastewater, Water Res., 41, 17901798, 2007.

Clair, T. A., Arp, P., Moore, T. R., Dalva, M., and Meng, F. R.: Gaseous carbon dioxide and methane, as well as dissolved organic carbon losses from a small temperate wetland under a changing climate, Environ. Pollut., 116, S143-S148, 2002.

Conley, D. J., Paerl, H. W., Howarth, R. W. Boesch, D. F., Seitzinger, S. P., Havens, K. E., Lancelot, C., and Likens, G. E.: Controlling eutrophication: Nitrogen and phosphorus, Science, 323, 1014-1015, 2009.

da Motta Marques D. M. L., Leite, G. R., and Giovannini, S. G. T.: Performance of two macrophyte species in experimental wetlands receiving variable loads of anaerobically treated municipal wastewater, Water Sci. Technol., 44, 311-316, 2001.

Drizo, A., Frost, C. A., Grace, J., and Smith, K. A.: Physicochemical screening of phosphate-removing substrates for use in constructed wetland systems, Wat. Res., 33, 3595-3602, 1999.

Dzakpasu, M., Hofmann, O., Scholz, M., Harrington, R., Jordan, S. N., and McCarthy, V.: Nitrogen removal in an integrated con- structed wetland treating domestic wastewater, J. Environ. Sci. Health, Part A, 46, 742-750, 2011.

Dzakpasua, M., Scholz, M., Harrington, R., Jordan, S. N., and McCarthy, V.: Characterising infiltration and contaminant migration beneath earthen-lined integrated constructed wetlands, Ecol. Eng., 41, 41-51, 2012.

Dzakpasu, M., Scholz, M., Harrington, R., McCarthy, V., and Jordan, S.: Groundwater Quality Impacts from a Full-Scale Integrated Constructed Wetland, Groundw. Monit. Remote, 34, 5164, 2014

Elberling, B., Louise A., Christian, J. J., Hans, P. J., Michael K., Ronnie N. G., and Frants, R. L.: Linking soil $\mathrm{O}_{2}, \mathrm{CO}_{2}$, and $\mathrm{CH}_{4}$ concentrations in a wetland soil: implications for $\mathrm{CO}_{2}$ and $\mathrm{CH}_{4}$ fluxes, Environ. Sci. Technol., 45, 3393-3399, 2011.

Fazzolari, C. E., Nicolardot, B., and Germon, J. C.: Simultaneous effects of increasing levels of glucose and oxygen partial pressures on denitrification and dissimilatory reduction to ammonium in repacked soil cores, Eur. J. Soil Biol., 34, 47-52, 1998.

Fenton, O., Healy, M. G., Brennan, F., Jahangir, M. M. R., Lanigan, G. J., Richards, K. G., Thornton, S. F., and Ibrahim, T. G.: Permeable reactive interceptors - blocking diffuse nutrient and greenhouse gas losses in key areas of the farming landscape, J. Agric. Sci., 152, S71-S81, 2014.

Fey, A., Benckiser, G., and Ottow, J. C. G.: Emissions of nitrous oxide from a constructed wetland using a ground filter and macrophytes in waste-water purification of a dairy farm, Biol. Fertil. Soils, 29, 354-359, 1999.

Findlay, S., Groffman, P., and Dye, S.: Effects of Phragmites australis removal on marsh nutrient cycling, Wetlands Ecol. Manage., 11, 157-165, 2003.

Firestone, M., Blazewicz, S., Peterson, D. G., and Placella, S.: Can molecular microbial ecology provide new understanding of soil nitrogen dynamics, edited by: Richards, K. G., Fenton, O., Watson, C. J., in: Proceedings of the 17th Nitrogen Workshop, 11$14,2012$.

Galloway, J. N., Aber, J. D., Erisman, J. W., Seitzinger, S. P., Howarth, R. W., Cowling, E. B., and Cosby, B. J.: The nitrogen cascade, BioSci., 53, 341-356, 2003.

Garcia, J., Capel, V., Castro, A., Ruiz, I., and Soto, M.: Anaerobic biodegradation tests and gas emissions from subsurface flow constructed wetlands, Bioresour. Technol., 98, 3044-3052, 2007.

Gray, N. F.: Drinking water quality: problems and solutions, 2nd edn., Cambridge Univ. Press, Cambridge, UK, 116-134, 2008

Grünfeld, S. and Brix, H.: Methanogenesis and methane emissions: effects of water table, substrate type and presence of Phragmites australis, Aquat,. Bot., 64, 63-75, 1999.

Gui, P., Inamori, R., Matsumura, M., and Inamori, Y.: Evaluation of constructedwetlands by waste water purification ability and greenhouse gas emissions, Water Sci. Technol., 56, 49-55, 2007.

Haroon, M. F., Hu, S., Shi, Y., Imelfort, M., Keller, J., Hugenholtz, P., Yuan, Z., and Tyson, G. W.: Anaerobic oxidation of methane coupled to nitrate reduction in a novel archaeal lineage, Nature, 500, 567-570, 2013.

Harrington, R., Carroll, P., Carty, A. H., Keohane, J., and Ryder, C.: Integrated constructed wetlands: concept, design, site evaluation and performance, Int. J. Water, 3, 243-255, 2007.

Healy, M. G., Rodgers, M., and Mulqueen, J.: Treatment of dairy wastewater using constructed wetlands and intermittent sand filters, Bioresour. Technol., 98, 2268-2281, 2007. 
Healy, M. G., Ibrahim, T. G., Lanigan, G., Serrenho, A. J., and Fenton, O.: Nitrate removal rate, efficiency and pollution swapping potential of different organic carbon media in laboratory denitrification bioreactors, Ecol. Eng., 40, 198-209, 2011.

Healy, M. G., Barrett, M., Lanigan, G. J., João Serrenho, A., Ibrahim, T. G., Thornton, S. F., Rolfe, S. A., Huang, W. E., and Fenton, O.: Optimizing nitrate removal and evaluating pollution swapping trade-offs from laboratory denitrification bioreactors, Ecol. Eng., 74, 290-301, 2014

Huygens, D., Trimmer, M., Rütting, T., Müller, C., Heppell, C. M., Lansdown, K., and Boeckx, P.: Biogeochemical N cycling in wetland ecosystems: ${ }^{15} \mathrm{~N}$ isotope techniques, Methods in biogeochemistry of wetlands, edited by: Reddy, K. R., Megonigal, J. P., and Delaune, R. D., Soil Sci. Soc. Amer., 30, 553-591, 2013.

Inamori, R., Gui, P., Dass, P., Matsumura, M., Xu, K.Q., Kondo, K., Ebie, Y., and Inamori, Y.: Investigating $\mathrm{CH}_{4}$ and $\mathrm{N}_{2} \mathrm{O}$ emissions from eco-engineering wastewater treatment processes using constructed wetland microcosms, Proc. Biochem, 42, 363373, 2007

IPCC: 2013 Supplement to the 2006 IPCC guidelines for national greenhouse gas inventories: wetlands, edited by: Hirashi, T., Krug, T., Tanabe, K., Srivastava, N., Baasansuren, J., Fukuda, M., Troxler, T. G., Switzerland, IPCC Task Force on National Greenhouse Gas Inventories, 354, 2013.

Islas-Lima, S., Thalasso, F., and Gomez-Hernandez, J.: Evidence of anoxic methane oxidation coupled to denitrification, Water Res., 38, 13-16, 2004.

Jahangir, M. M. R., Johnston, P., Grant, J., Somers, C., Khalil, M. I., and Richards, K. G.: Evaluation of headspace equilibration methods for measuring greenhouse gases in groundwater, J. Environ. Manage., 111, 208-212, 2012.

Jahangir, M. M. R., Johnston, P., Addy, K., Khalil, M. I., Groffman, P., and Richards, K. G.: Quantification of in situ denitrification rates in groundwater below an arable and a grassland system, Water Air Soil Pollut., 224, 1693, doi:10.1007/s11270-013-1693-z, 2013.

Johansson, A. E., Kasimir-Klemedtsson, A., Klemedtsson, L., and Svensson, B. H.: Nitrous oxide exchanges with the atmosphere of a constructed wetland treating wastewater, Tellus, 55B, 737-750, 2003.

Johansson, A. E., Gustavsson, A. M., Öquist, M. G., and Svensson, B. H.: Methane emissions from a constructed wetland treating wastewater - seasonal and spatial distribution and dependence on edaphic factors, Water Res., 38, 3960-3970, 2004.

Johansson, E.: Constructed wetlands and deconstructed discorsesgreenhouse gas fluxes and discorses on purifying capacities, Dept. Water Environ. Studies, Linköping Univ., Sweden, 2002.

Kalyuzhnyi, S., Gladchenko, M., Mulder, A., and Versprille, B.: DEAMOX-new biological nitrogen, Water Res., 40, 3637-3645, 2006.

Kana, T. M., Darkangelo, C., Hunt, M. D., Oldham, J. B., Bennett, G. E, and Cornwell, J. C.: Membrane inlet mass spectrometer for rapid high precision determination $\mathrm{N}_{2}, \mathrm{O}_{2}$ and $\mathrm{Ar}$ in environmental water samples, Anal. Chem., 66, 4166-4170, 1994.

Kato, K., Koba, T., Ietsugu, H., Saigusa, T., Nozoe, T., Kobayashi, S., Kitagawa, K., and Yanagiya, S.: Early performance of hybrid reed bed system to treat milking parlour wastewater in cold climate in Japan, in: 10th international conference wetland systems for water pollution control, MAOTDR, Lisbon, Portugal, 11111118, 2006.

Kellogg, D. Q., Gold, A. J., Groffman, P. M., Addy, K., Stolt, M. H., and Blazejewski, G.: In situ groundwater denitrification in stratified, permeable soils underlying riparian wetlands, J. Environ. Qual., 34, 524-533, 2005.

Kelso, B. H. L., Smith, R. V., Laughlin, R. J., and Lennox, S. D.: Dissmilatory nitrate reduction in anaerobic sediments leading to river nitrate accumulation, Appl. Enviro. Microbiol., 63, 46794685, 1997.

Korom, S. F.: Natural denitrification in the saturated zone: a review, Water Resour. Res., 28, 1657-1668, 2002.

Koskiaho, J., Ekholm, P., Räty, M., Riihimäki, J., and Puustinen, M.: Retaining agricultural nutrients in constructed wetlands- experiences under boreal conditions, Ecol. Eng., 20, 89-103, 2003.

Laanbroek, H. J.: Bacterial cycling of minerals that affect plant growth in waterlogged soils: a review, Aquat. Bot., 38, 109-125, 1990.

Laanbroek, H. J.: Methane emission from natural wetlands: interplay between emergent macrophytes and soil microbial processes, A mini-review, Ann. Bot., 105, 141-153, 2010.

Langergraber, G.: Modeling of processes in subsurface flow constructed wetlands: A review. Vadose Zone, J. 7, 830-842, 2008.

Lee, C., Fletcher, T. D., and Sun, G.: Nitrogen removal in constructed wetland systems, Eng. Life Sci., 9, 11-22, 2009.

Liikanen, A., Huttunen, J. T., Kaijalainen, S. M., Heikkinen, K. Vdisdinen, T. S., Nykiinen, H., and Martikainen, P. J.: Temporal and seasonal changes in greenhouse gas emissions from a constructed wetland purifying peat mining runoff water, Ecol. Eng., 26, 241-251, 2006.

Liu, C., Xu, K., Inamori, R., Ebie, Y., Liao, J., and Inamori, Y.: Pilot-scale studies of domestic wastewater treatment by typical constructed wetlands and their greenhouse gas emissions, Front. Environ. Sci. Eng. China, 3, 477-482, 2009.

Luederitz, V., Eckert, E., Lange-Weber, M., Lange, A., and Gersberg, R. M.: Nutrient removal efficiency and resource economics of vertical flow and horizontal flow constructed wetlands, Ecol. Eng., 18, 157-171, 2001.

Luo, W. G., Wang, S. H., Huang, J., and Qian, W. Y.: Denitrification by using subsurface constructed wetland in low temperature, China Water Wastewater, 21, 37-40, 2005.

Makino, W., Cotner, J. B., Sterner, R. W., and Elser, J. J.: Are bacteria more like plants or animals? Growth rate and resource dependence of bacterial C:N:P stoichiometry, Funct. Ecol., 17, 121130, 2003.

Maltais-Landry, G., Maranger, R., Brisson, J., and Chazarenc, F.: Greenhouse gas production and efficiency of planted and artificially aerated constructed wetlands, Environ. Pollut., 157, 748754, 2009.

Mander, Ü., Lõhmus, K., Teiter, S., Nurk, K., Mauring, T., and Augustin, J.: Gaseous fluxes from subsurface flow constructed wetlands for wastewater treatment, J. Environ. Sci. Health A 40, 1215-1226, 2005.

Mander, U., Lõhmus, K., Teiter, S., Mauring, T., Nurk, K., and Augustin, J.: Gaseous fluxes in the nitrogen and carbon budgets of subsurface flow constructed wetlands, Sci. Total Environ., 404, 343-353, 2008.

Mander, Ü., Maddison, M., Soosaar, K., and Karabelnik, K.: The impact of intermit-tent hydrology and fluctuating water table on 
greenhouse gas emissions from subsurface flow constructed wetlands for wastewater treatment, Wetlands, 31, 1023-1032, 2011. Mander, Ü., Dotro, G., Ebie, Y., Towprayoon, S., Chiemchaisri, C., Nogueira, S. F., Jamsranjav, B., Kasak, K, Truu, J., Tournebize, J., and Mitsch, W. J.: Greenhouse gas emission in constructed wetlands for wastewatertreatment: A review, Ecol. Eng., 66, 1935, 2014.

Minett, D. A., Cook, P. L. M., Kessler, A. J., and Cavagnaro, T. R.: Root effects on the spatial and temporal dynamics of oxygen in sand-based laboratory-scale constructed biofilters, Ecol. Eng., 58, 414-422, 2013.

Mitsch, W. J. and Gosselink, J. G.: Wetlands, 3rd Edn. New York, John Wiley \& Sons, p. 936, 2000.

Müller, C. and Bünemann, E. K.: A ${ }^{33} \mathrm{P}$ tracing model for quantifying gross $\mathrm{P}$ transformation rates in soil, Soil Biol. Biochem., 76, 218-226, 2014.

Müller, C. and Clough, T. J.: Advances in understanding nitrogen flows and transformations: gaps and research pathways, J. Agril. Sci., 152, S1, 34-44, 2014.

Müller, C., Laughlin, R. J., Spott, O., and Rütting, T.: Quanti?cation of $\mathrm{N}_{2} \mathrm{O}$ emission pathways via a ${ }^{15} \mathrm{~N}$ tracing model, Soil Biol. Biochem., 72, 44-54, 2014.

Mustafa, A. and Scholz, M.: Nutrient accumulation in Typha latifolia $\mathrm{L}$. and sediment of a representative integrated constructed wetland, Water Air Soil Pollut., 219, 329-341, 2011.

Nguyen, L. M.: Organic matter composition, microbial biomass and microbial activity in gravel-bed constructed wetlands treating farm dairy wastewaters, Ecol. Eng., 16, 199-221, 2000.

O'Luanaigh, N. D., Goodhue, R., and Gill, L. W.: Nutrient removal from on-site domestic wastewater in horizontal subsurface flow reed beds in Ireland, Ecol. Eng., 36, 1266-1276, 2010.

Obarska-Pempkowiak, H. and Gajewska, M.: The dynamics of processes responsible for transformation of nitrogen compounds in hybrid wetlands systems in a temperate climate, in: WetlandsNutrients, Metals and Mass Cycling, edited by: Vymazal, J., Backhuys Publishers, Leiden, The Netherlands, 129-142, 2003.

Pangala, S. R., Reay, D. S., and Heal, K. V.: Mitigation of methane emissions from constructed farm wetlands, Chemosphere, 78, 493-499, 2010.

Parkin, T. B.: Soil microsites as a source of denitrification variability, Soil Sci. Am. J., 51, 1194-1199, 1987.

Payne, E. G. I., Fletcher, T. D., Cook, P. L. M., Deletic, A., and Hatt, B. E.: Processes and drivers of nitrogen removal in stormwater biofiltration, Crit. Rev. Environ. Sci. Technol., 44, 796-846, 2014a.

Payne, E. G. I., Fletcher, T. D., Russell, D. G., Grace, M. R., Cavagnaro, T. R., Evrard, V., Deletic, A., Hatt, B. E., and Cook, P. L. M.: Temporary storage or permanent removal? The division of nitrogen between biotic assimilation and denitrification in stormwater biofiltration systems, PLoS ONE, 9, e90890, 2014b.

Peterson, D. G., Blazewicz, S., Herman, D. J., Firestone, M., Turetsky, M., and Waldrop, M.: Abundance of microbial genes associated with nitrogen cycling as indices of biogeochemical process rates across a vegetation gradient in Alaska, Environ. Microbiol., 14, 993-1008, 2012.

Pett-Ridge, J., Silver, W. L., and Firestone, M. K.: Redox fluctuations frame microbial community impacts on $\mathrm{N}$-cycling rates in humid tropical forest soil, Biogeochem., 81, 95-110, 2006.
Poach, M. E., Hunt, P. G., Vanotti, M. B., Stone, K. C., Matheny, T. A., Johnson, M. H., and Sadler, E. J.: Improved nitrogen treatment by constructed wetlands receiving partially nitrified liquid swine manure, Ecol. Eng., 20, 183-197, 2003.

Rabalais, N. N., Díaz, R. J., Levin, L. A., Turner, R. E., Gilbert, D., and Zhang, J.: Dynamics and distribution of natural and humancaused hypoxia, Biogeosciences, 7, 585-619, doi:10.5194/bg-7585-2010, 2010.

Reay, D. S.: Fertilizer 'solution' could turn local problem global - Protecting soil and water from pollution may mean releasing more greenhouse gas, Nature, 427, 485-485, 2004.

Reddy, K. R. and Delaune, R. D.: Biogeochemistry of Wetlands: Science and Applications, CRC Press, 800 pp., 2008.

Riya, S., Zhou, S., Nakashima, Y., Terada, A., and Hosomi, M.: Direct and indirect greenhouse gas emissions from vertical flow constructed wetland planted with forage rice, Kagaku Kogaku Ronbunshu, 36, 229-236, 2010.

Rütting, T. and Müller, C.: Process-specific analysis of nitrite dynamics in a permanent grassland soil by using a Monte Carlo sampling technique, Euro. J. Soil Sci., 59, 208-215, 2008.

Rütting, T., Boeckx, P., Müller, C., and Klemedtsson, L.: Assessment of the importance of dissimilatory nitrate reduction to ammonium for the terrestrial nitrogen cycle, Biogeosci., 8, 11691196, 2011.

Seitzinger, S. P., Sanders, R. W., and Styles, R.: Bioavailability of DON from natural and anthropogenic sources to estuarine plankton, Limnol. Oceanogr., 47, 353-366, 2002.

Sha, C. Y., Mitsch, W. J., Mander, Ü., Lu, J. J., Batson, J., Zhang, L., and He, W. S.: Methane emissions from freshwater riverine wetlands, Ecol. Eng., 37, 16-24, 2011.

Shamir, E., Thompson, T. L., Karpisak, M. M., Freitas, R. J., and Zauderer, J.: Nitrogen accumulation in a constructed wetland for dairy wastewater treatment, J. Amer. Water Resour. Assoc., 37, 315-325, 2001.

Song, K., Lee, S. H., Mitsch, W. J., and Kang, H.: Different responses of denitrification rates and denitrifying bacterial communities to hydrological pulses in created wetlands, Soil Biol. Biochem., 42, 1721-1727, 2010.

Song, K., Lee, S. H., and Kang, H.: Denitrification rates and community structure of denitrifying bacteria in newly constructed wetland, Eur. J. Soil Biol., 47, 24-29, 2011.

Søvik, A. K., Augustin, J., Heikkinen, K., Huttunen, J. T., Necki, J. M., Karjalainen, S. M., Klove, B., Liikanen, A., Mander, U., Puustinen, M., Teiter, S., and Wachniew, P.: Emission of the greenhouse gases nitrous oxide and methane from constructed wetlands in Europe. J. Environ, Qual., 35, 2360-2373, 2006.

Stadmark, J. and Leonardson, L.: Emissions of greenhouse gases from ponds constructed for nitrogen removal, Ecol. Eng., 25, 542-551, 2005.

Ström, L., Ekberg, A., Mastepanov, M., and Christensen, T. R.: The effect of vascular plants on carbon turnover and methane emissions from a tundra wetland, Global Change Biol. 9, 1185-1192, 2003.

Ström, L., Mastepanov, M., and Christensen, T. R.: Species specific effects of vascular plants on carbon turnover and methane emissions from wetlands, Biogeochem., 75, 65-82, 2005.

Ström, L., Lamppa, A., and Christensen, T. R.: Greenhouse gas emissions from a constructed wetland in southern Sweden, Wetlands Ecol. Manage., 15, 43-50, 2007. 
Tai, P. D., Li, P. J., Sun, T. H., He, Y. W., Zhou, Q. X., Gong, Z. Q., Mizuochi, M., and Inamori, Y.: Greenhouse gas emissions from a constructed wetland for municipal sewage treatment, J. Environ. Sci. China, 14, 27-33, 2002.

Takaya, N.: Dissimilatory nitrate reduction metabolisms and their control in fungi, J. Biosci. Bioeng., 94, 506-510, 2002.

Tanner, C. C., Nguyen, M. L., and Sukias, J. P. S.: Nutrient removal by a constructed wetland treating subsurface drainage from grazed dairy pasture, Agric. Ecosysts. Environ., 105, 145$162,2005$.

Teiter, S. and Mander, Ü.: Emission of $\mathrm{N}_{2} \mathrm{O}, \mathrm{N}_{2}, \mathrm{CH}_{4}$ and $\mathrm{CO}_{2}$ from constructed wetlands for wastewater treatment and from riparian buffer zones, Ecol. Eng., 25, 528-541, 2005.

Thayalakumaran, T., Bristow, K. L., Charlesworth, P. B., and Fass, T.: Geochemical conditions in groundwater systems: Implications for the attenuation of agricultural nitrate, Agril. Water Manage., 95, 103-115, 2008.

Toet, S., Richards, S. P., van Logtestijn, Kamp, R., Schreijer, M., and Verhoeven, J. T. A.: The effect of hydraulic retention time on the performance of pollutants from sewage treatment plant effluent in a surface flow constructed wetland system, Wetlands, 25, 375-391, 2005.

Van der Zaag, A. C., Gordon, R. J., Burton, D. L., Jamieson, R. C., and Stratton, G. W.: Greenhouse gas emissions from surface flow and subsurface flow constructed wetlands treating dairy wastewater, J. Environ. Qual., 39, 460-471, 2010.

Van Oostrom, A. J. and Russell, J. M.: Denitrification in constructed wastewater wetlands receiving high concentrations of nitrate, Water Sci. Technol., 29, 7-14, 1994.

Verhoeven, J. T. A. and Meuleman, A. F. M.: Wetlands for wastewater treatment: Opportunities and limitations, Ecol. Eng., 12, 5$12,1999$.

Vymazal, J.: Removal of nutrients in various types of constructed wetlands, Sci. Total Environ., 380, 48-65, 2007.

Vymazal, J. and Kröpfelová, L.: Types of constructed wetlands for wastewater treatment in: Wastewater Treatment in Constructed Wetlands with Horizontal Sub-Surface Flow, Environmental Pollution Springer, Heidelberg, 121-202, 2010.

Wang, H., Huang, C., Ge, Y., zhi Wu, J., and Chang, J.: The Performance of Species Mixtures in Nitrogen and Phosphorus Removal at Different Hydraulic Retention Times, Pol. J. Environ. Stud., 23, 917-922, 2014.

Weerakoon, G. M .P. R., Jinadasa, K. B. S. N., Herath, G. B. B., Mowjood, M. I. M., and van Bruggen, J. J. A.: Impact of the hydraulic loading rate on pollutants removal in tropical horizontal subsurface flow constructed wetlands, Ecol. Eng., 61, 154-160, 2013.
Whalen, S. C.: Biogeochemistry of methane exchange between natural wetlands and the atmosphere, Environ. Eng. Sci., 22, 73-94, 2005.

Wild, U., Lenz, A., Kamp, T., Heinz, S., and Pfadenhauer, J.: Vegetation development, nutrient removal and trace gas fluxes in constructed Typha wetlands, in: Natural wetlands for wastewater treatment in cold climates, edited by: Mander, Ü., Jenssen P. D., Adv. Ecol. Sci., Southampton, Boston, WIT Press, 101-126, 2002.

Wunderlin, P., Lehmann, M. F., Siegrist, H., Tuzson, B., Joss, A., Emmenegger, L., and Mohn, J.: Isotope signatures of $\mathrm{N}_{2} \mathrm{O}$ in a mixed microbial population system: constraints on $\mathrm{N}_{2} \mathrm{O}$ producing pathways in wastewater treatment. Environ. Sci. Technol., 47, 1339-1348, 2013.

Wynn, T. M. and Liehr, S. K.: Development of a constructed subsurface-flow wetland simulation model, Ecol. Engg., 16, 519-536, 2001.

Xue, Y., Kovacic, D. A., David, M. B., Gentry, L. E., Mulvaney, R. L., and Lindau, C. W.: In situ measurements of denitrification in constructed wetlands, J. Environ. Qual., 28, 263-269, 1999.

Yan, C., Zhang, H., Li, B., Wang, D., Zhao, Y., and Zheng, Z.: Effects of influent $\mathrm{C} / \mathrm{N}$ ratios on $\mathrm{CO}_{2}$ and $\mathrm{CH}_{4}$ emissions from vertical subsurface flow constructed wetlands treating synthetic municipal wastewater, J. Hazardous Mat., 203-204, 188-194, 2012.

Yavitt, J. B. and Knapp, A. K.: Aspects of methane flow from sediment through emergent cattail (Typha latifolia) plants, New Phytol., 139, 495-503, 1998.

Yin, S., Shen, Q., Tang, Y., and Cheng, L.: Reduction of nitrate to ammonium in selected paddy soils in China, Pedosphere, 8, 221228, 1998.

Zhang, J., Shao, W. S., He, M., Hu, H. Y., and Gao, B. Y.: Treatment performance and enhancement of subsurface constructed wetland treating polluted river water in winter, Environ. Sci., 27, 1560-1564, 2006.

Zhao, Y., Zhang, Y., Ge, Z., Hu, C., and Zhang, H.: Effects of influent $\mathrm{C} / \mathrm{N}$ ratios on wastewater nutrient removal and simultaneous greenhouse gas emission from the combinations of vertical subsurface flow constructed wetlands and earthworm eco-filters for treating synthetic wastewater, Environ. Sci. Proc. Impacts, 16, 567-575, 2014. 